\title{
Presumption of Innocence or Presumption of Mercy?: Weighing Two Western Modes of Justice
}

\author{
James Q. Whitman*
}

American criminal law has a deep commitment to the presumption of innocence. Yet at the same time, American criminal justice is, by international standards, extraordinarily harsh. This Article addresses this troubling state of affairs. The Article contrasts the American approach with the approach of the inquisitorial tradition of continental Europe. Inquisitorial justice, it argues, has a less far-reaching presumption of innocence than American justice does. Yet if continental justice puts less weight on the rights of the innocent, it puts more on the rights of the guilty: while its presumption of innocence is comparatively weaker, it has what can be called a strong presumption of mercy. The continental approach produces forms of criminal procedure that can shock Americans. Continental trial in particular often seems to American observers to operate on a disturbing de facto presumption of guilt; the most recent example is the high-profile trial of Amanda Knox. Yet the continental approach has contributed to the making of a significantly more humane criminal justice system than ours. Moreover, the continental approach is better suited to cope with the rise of new forms of scientific investigation. The Article pleads for a shift away from the American culture of rights for the innocent toward a greater concern with continental-style rights for the guilty.

\section{Introduction}

Imagine two contrasting ideas of how to build a just system of criminal justice. The first is oriented toward the presumption of innocence. It starts from the belief that the gravest danger we face in criminal justice is the danger that innocent persons will be arrested, prosecuted, and convicted. Accordingly, it focuses on the threat of abusive investigations and prejudicial trials-on the dangers posed by rogue cops, unprincipled prosecutors, and biased judges and juries, all of whom threaten to

* Ford Foundation Professor of Comparative and Foreign Law, Yale University. Earlier versions of this Article were presented at workshops at Boston University Law School, Harvard Law School, the University of Virginia Law School, the Princeton University Program in Law and Public Affairs, and the Interdisciplinary Roundtable on Punitiveness in America at John Jay College of the City University of New York. I am grateful to participants in all of these fora. My thanks for comments, criticism, and pointers to Alice Ristroph, Rachel Barkow, Issa KohlerHausmann, Antoine Garapon, Emanuele Conte, Hanoch Dagan, William Simon, Tatjana Hörnle, Alec Walen, John Langbein, Jacqueline Ross, and Michael Tonry. The Article was written during a lovely fellowship year at Princeton's Law and Public Affairs Program, to which I express my warmest gratitude. 
undermine the liberties and the privacy of citizens. Committed to combatting those dangers, this mode of justice invests in what Herbert Packer famously called the "obstacle course" conception of due process: it protects the interests of justice by making it maximally difficult for the state to prove the case against defendants. ${ }^{1}$ To that end, it makes it hard for investigators to assemble evidence, and hard for prosecutors to manipulate the jury. It offers far-reaching protections to those persons who are suspected or accused. Once defendants have been duly convicted, however, it does little to protect them. Its rights are rights for the innocent, not the guilty.

The second, contrasting idea of how to build a just criminal justice system is oriented instead toward a different presumption, a presumption of mercy. This mode of justice does not treat the danger that innocent persons will be convicted as the most pressing danger posed by the state. On the contrary, it tends to operate on the workaday assumption that investigators and judicial personnel are trustworthy professionals, and that virtually all accused persons are guilty as charged. In consequence, it puts lesser weight on due process protections for the accused. But that does not mean that it lacks rights: while this alternative mode of justice puts lesser weight on protections for the innocent, it puts greater weight on protections for the guilty. The most dangerous threat to justice, on this second view, is not the state that engages in rogue investigations or unfair trials, but the state that inflicts excessive punishment. The greatest fear is not that the innocent will be convicted, but that the guilty will be treated in inhumane ways. By erecting a presumption of mercy, this approach aims to force the justice system to think carefully and work hard before it carries out a criminal penalty.

These two modes of justice exist in the contemporary West, as this Article aims to show. The first, the mode of justice oriented toward the presumption of innocence, dominates in the criminal justice of the United States. The second mode, oriented toward the presumption of mercy, is much more powerfully present in the inquisitorial traditions of continental Europe.

And of these two Western modes of justice, the first-our familiar, American mode, oriented toward the presumption of innocence-is troubled and increasingly fragile. The deep American attachment to what Packer called the ideology of a "presumption of innocence"2 has failed to create a humane criminal justice system. On the contrary, our tendency to think of the interests of justice as interests in protecting the innocent, not the guilty, has contributed to the making of an extraordinarily harsh culture

1. Herbert L. Packer, Two Models of the Criminal Process, 113 U. PA. L. REV. 1, 13 (1964).

2. Id. at 12 . 
of criminal punishment-one that threatens all of us, black and white, rich and poor. Meanwhile, the rise of modern scientific evidence is making our conception of due process more and more difficult to sustain. The continental mode of justice, oriented more toward the presumption of mercy, certainly has its dangers and shortcomings, but on balance it is better suited to creating a just criminal justice order for the modern world. Americans of goodwill should feel uneasy about our culture of the presumption of innocence, and they should be prepared to ponder the inquisitorial presumption of mercy with an open mind.

Those are my claims. I offer them at a moment when mercy is much on the American agenda. There is a widespread sense of crisis in American criminal justice-a sense on both the right and the left that our punishment practices have spun out of control. ${ }^{3}$ In the face of this crisis, the President has made a point of making highly publicized use of his clemency power. ${ }^{4}$ Meanwhile, scholars of criminal law are dividing into two hostile campsone advocating mercy, ${ }^{5}$ the other deploring it ${ }^{6}$-while at least one author has published a bold argument against our strong American orientation toward protecting the innocent as the road to the creation of a humane system. ${ }^{7}$ My hope at this juncture is to bring a deeper understanding of the workings of mercy in the law by looking beyond our borders to countries where criminal justice has taken on less fearsome forms than it has here at home. If there is something to learn from non-American justice, the time has come to learn it.

3. E.g., Carl Hulse, Unlikely Cause Unites the Left and Right: Justice Reform, N.Y. TIMES (Feb. 18, 2015), http://www.nytimes.com/2015/02/19/us/politics/unlikely-cause-unites-the-leftand-the-right-justice-reform.html [https://perma.cc/KYE6-2TVR] (describing bipartisan advocacy within the Coalition for Public Safety to overhaul the prison and justice systems); Colleen McCain Nelson \& Gary Fields, Obama, Koch Brothers in Unlikely Alliance to Overhaul Criminal Justice, WALL STREET J. (July 16, 2015, 8:03 PM), http:/www.wsj.com/articles/obama-koch-brothers-in -unlikely-alliance-to-overhaul-criminal-justice-1437090737 [https://perma.cc/5Z93-BHHY] (describing a collaboration between the Democratic White House and Republican donors to reform federal sentencing laws and other aspects of the criminal justice system).

4. E.g., Peter Baker, Obama Plans Broader Use of Clemency to Free Nonviolent Drug Offenders, N.Y. TiMES (July 3, 2015), http:/www.nytimes.com/2015/07/04/us/obama-plansbroader-use-of-clemency-to-free-nonviolent-drug-offenders.html [https://perma.cc/7M3U-MHLE] (arguing that President Obama is using his clemency power as part of a broader effort to correct oversentencing).

5. See, e.g., Rachel E. Barkow \& Mark Osler, Restructuring Clemency: The Cost of Ignoring Clemency and a Plan for Renewal, 82 U. CHI. L. REV. 1, 7 (arguing that mercy should be a priority for the office of the presidency under the pardon power).

6. See, e.g., Paul H. Robinson, Obama's Get-Out-of-Jail-Free Decree, WALL STREET J. (July 14, 2015, 7:28 PM), http:/www.wsj.com/articles/obamas-get-out-of-jail-free-decree -1436916535 [https://perma.cc/F9S6-AB7G] (arguing that using clemency to override existing policy on criminal sentences sets a dangerous precedent for presidential use of the pardon power).

7. See Daniel Epps, The Consequences of Error in Criminal Justice, 128 HARV. L. REV. 1065, 1110-21 (2015) (criticizing the criminal justice system's preference for false acquittals over false convictions through an analysis of the detrimental effects on the criminal justice system as a whole). 


\section{Culture Clash in Criminal Justice}

People in every part of the Western world agree on the same proposition, banal but fundamental: A civilized society must impose limits on the state in its conduct of criminal justice. That is equally true of both of the great Western traditions that now dominate throughout most of the globe-the adversarial tradition of the common law and the inquisitorial tradition of continental Europe. It is easy to amass quotes from both the common law countries and the Continent that warn of the dangers of government abuses: unless we are vigilant, we hear in America, we may find ourselves living in a "police state"; 8 there are pressing risks of "repressive excess," official French documents remind us, that call for close constitutional oversight of criminal justice;" a society of the rule of law, we read in the German newspapers, is a society that must keep the criminal justice system in a judicial "corset",, 10 and so on. But if we all agree that government presents dangers, we differ over what those dangers are and what sorts of limits to impose-so much so that Americans are sometimes puzzled and even shocked by what goes on in inquisitorial Europe, while Europeans can be equally puzzled and shocked by what goes on in adversarial America.

Begin with what Americans find puzzling and shocking about the inquisitorial systems of continental Europe. Much of it involves criminal investigation. Suspicion of government investigators has been a constant in American legal culture since the eighteenth century and today it is an American commonplace that Fourth Amendment protections against the threat of investigative abuses are essential-indeed "more essential than ever," as Stephen Schulhofer proclaims-in the twenty-first age of hightech investigation. ${ }^{11}$ Safeguarding liberty, to us, begins with a healthy distrust of government and most especially of government investigators.

Yet continental democracies like France, Germany, and Italy have nothing quite like our Fourth Amendment. To be sure, continental magistrates and police do not have carte blanche. There is quite a bit of

8. Sal Gentile, Are We Becoming a Police State? Five Things that Have Civil Liberties Advocates Nervous, DAILY NEED (Dec. 7, 2011), http://www.pbs.org/wnet/need-to-know/the -daily-need/are-we-becoming-a-police-state-five-things-that-have-civil-liberties-advocatesnervous/12563/ [http://perma.cc/Q2WU-M9XU].

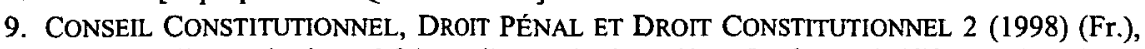
http://www.conseil-constitutionnel.fr/conseil-constitutionnel/root/bank_mm/pdf/Conseil/penal.pdf [http://perma.cc/KZ98-CQ7C].

10. Günter Bertram, Geschichte im Korsett des politischen Strafrechts: Meinungsfreiheit im "freien Westen" [History in the Corset of Political Criminal Law: Freedom of Speech in the "Free West'], 2010 DeUTSCHLAND JouRNAL 31, 39 (Ger.), http://www.deutschlandjournal.de/ Deutschland_Journal___Jahresau/Deutschland_Journal__Jahresau/06Geschichte_im_Korsett_des _politischen_Strafrechts_DJ2010.pdf [https://perma.cc/XR9Q-ZCL2].

11. STEPHEN J. SCHULHOFER, MORE ESSENTIAL THAN EVER: THE FOURTH AMENDMENT IN THE TWENTY-FIRST CENTURY 180 (2012). 
regulation of the investigative process in all of the continental countries, and some of that regulation bears a resemblance to our Fourth Amendment jurisprudence, at least on paper. ${ }^{12}$ Europeans certainly claim to be concerned with putting limits on state investigators. Nevertheless, in practice they are prepared to strike a pragmatic balance between reining in investigators and seeking the full truth, ${ }^{13}$ and the result is that continental investigators periodically engage in practices that seem to Americans disturbingly out of line.

Take a few recent examples that have made their way into the American press. In France, former President Nicolas Sarkozy was indicted by investigating magistrates on the basis of wiretaps on conversations they ordered between him and his lawyer. That news triggered a flurry of American reports about the "sweeping powers" of French investigators ${ }^{14}$ and the "disturbing" conduct of the "the French justice system." Is Isn't such casual disregard for attorney-client privilege, Americans ask, worrisome? Other French cases that are sure to worry Americans have recently hit the papers as well. ${ }^{16}$ The Germans too can sometimes seem to

12. The European Court of Human Rights in particular has dedicated itself to keeping criminal investigation within bounds, as have the national traditions. See Stephen C. Thaman, Criminal Courts and Procedure, in COMPARATIVE LAW AND SOCIETY 235, 246-48 (David S. Clark ed., 2012) (describing ways in which adversarial procedure has gradually replaced aspects of the European inquisitorial model of criminal justice). Some of the reform efforts provoke resistance from European police. See, e.g., Un syndicat policier dénonce "l'alourdissement" de la procédure pénale, 20 MINUTES (Jan. 29, 2014, 1:22 PM) (Fr.), http://www.20minutes.fr/france/ 967347-20120706-syndicat-policier-denonce-l-alourdissement-procedure-penale [http://perma.cc/ YB94-68JT] (quoting French police officers denouncing increased criminal procedures).

13. This is a strong tendency accompanied by considerable discretion vested in judges. See Sabine Gless, Germany: Balancing Truth Against Protected Constitutional Interests, in EXCLUSIONARY RULES IN COMPARATIVE LAW 113, 114-15 (Stephen C. Thaman ed., 2013) (for German balancing); Giulio Illuminati, Italy: Statutory Nullities and Non-Usability, in EXCLUSIONARY RULES IN COMPARATIVE LAW, supra, at 235, 237-38 (for Italian limitations on exclusion); Jean Pradel, France: Procedural Nullities and Exclusion, in EXCLUSIONARY RULES IN COMPARATIVE LAW, supra, at 145, 152-53 (for French protection of the home). See also the overall learned assessment of Professor Stephen C. Thaman, Balancing Truth Against Human Rights: A Theory of Modern Exclusionary Rules, in EXCLUSIONARY RULES IN COMPARATIVE LAW, supra, at 403.

14. A Scandal Tainting Both Sides, ECONOMIST (Mar. 15, 2014), http://www.economist.com/ news/europe/21599064-nicolas-sarkozys-political-comeback-endangered-scandal-tainting-bothsides [http://perma.cc/7MWZ-CTXH].

15. Marc Champion, Eavesdropping on Sarkozy, BLOOMBERGVIEW (July 4, 2014, 8:00 AM), http://www.bloombergview.com/articles/2014-07-04/eavesdropping-on-sarkozy [http://perma.cc/ 6BNM-BATD].

16. Notably a mass DNA sweep in La Rochelle conducted under the threat that noncooperators would simply be arrested. See Pauline Boyer, Viol à La Rochelle: "On se dit qu'il y a un prédateur parmi nous," LE FIGARO.FR (Apr. 14, 2014, 11:42 AM) (Fr.), http://www.lefigaro.fr/actualite-france/2014/04/14/01016-20140414ARTFIG00087-viol-a-la -rochelle-on-se-dit-qu-il-y-a-un-predateur-parmi-nous.php [http://perma.cc/3MNL-TC2T] (describing French reactions to a justice ordering DNA testing of 527 men present at the time a student was raped). No perpetrator was identified. Viol d'une lycéenne à La Rochelle: les tests 
Americans alarmingly insensitive to basic Fourth Amendment imperatives. German investigators make heavy use of electronic surveillanceincluding, notoriously, a police Trojan Horse program ${ }^{17}$-and even outrageous abuses do not necessarily result in suppression of evidence. ${ }^{18}$ "Europe won't save you[!]," warns one site about German investigative practices, your "e-mail is probably safer in the U.S." 19 Not least, there is a hotly discussed Italian example from a case that I will touch on throughout this Article: the sensational trial of Amanda Knox, the Seattle exchange student charged with an ugly murder in the small Italian city of Perugia in 2007. In the course of an intense public-relations battle over her guilt, Knox's parents alleged that police interrogators had coerced their daughter into falsely incriminating herself. ${ }^{20}$ The consequence was that they themselves were indicted for criminal defamation of the police! $!^{21}$ What kind of free country, Americans ask, brings a criminal prosecution against people because they have the temerity to raise questions about a police investigation? Is liberty really safe in a society where such things go on?

But it is not just inquisitorial criminal investigation that can occasionally make Americans shake their heads. The same is also trueeven more true - of inquisitorial trial procedure. American trial procedure is founded on a careful bifurcation of the criminal trial into the guilt phase and the sentencing phase. ${ }^{22}$ During the initial guilt phase, American law

ADN négatifs, LE MONDE (May 21, 2014, 7:32 PM) (Fr.), http://www.lemonde.fr/societe/article/ 2014/05/21/viol-d-une-lyceenne-a-la-rochelle-les-test-adn-negatifs_4423264_3224.html [http:// perma.cc/XY63-9SJ5].

17. Monika Ermert, Brief: German Police Used Trojan Horses in Investigations, INTELL. PROP. WATCH (Oct. 10, 2011), http:/www.ip-watch.org/2011/10/10/german-police-used-trojan -horses-in-investigations/ [http://perma.cc/Sz6P-A23N].

18. In general, German investigations are subject to proportionality limits. See CHRISTIAN JÄGER, BEWEISVERWERTUNG UND BEWEISVERWERTUNGSVERBOTE IM STRAFPROZESS 4-12 (2003) (Ger.). For the application of these principles to the Trojan Horse program, see Frederik Obermaier \& Pascal Paukner, Bundestrojaner ist einsatzbereit, SÜDDEUTSCHE ZEITUNG (Aug. 15, 2014, 12:29 AM) (Ger.), http://www.sueddeutsche.de/digital/online-ueberwachung -bundestrojaner-ist-einsatzbereit-1.2090112 [https://perma.cc/QG2P-RWZG]. For earlier literature, see Joachim Bohnert, Ordnungsvorschriften im Strafverfahren, 1982 NEUE ZEITSCHRIFT FÜR STRAFRECHT 5 (Ger.); and Hans-Joachim Rudolphi, Revisibilität von Verfahrensmängeln im Strafprozeß, in MONATSSCHRIFT FÜR DEUTSCHES RECHT 93 (1970) (Ger.).

19. Cyrus Farivar, Europe Won't Save You: Why E-Mail is Probably Safer in the US, ARS TECHNICA (Oct. 13, 2013, 4:00 PM), http://arstechnica.com/tech-policy/2013/10/europe-wont -save-you-why-e-mail-is-probably-safer-in-the-us/2/ [http://perma.cc/NE4W-GFRR].

20. Stacy Meichtry, Italian Judge Indicts Amanda Knox's Parents, WALL STREET J. (Feb. 15, 2011 , $4: 54$ PM), http://www.wsj.com/articles/ SB 10001424052748703312904576146641422780606 [https://perma.cc/759U-3SFM].

21. Doug Longhini, Amanda Knox's Parents to Go on Trial in Perugia, CBS NEwS (Mar. 20, 2012, 11:49 AM), http://www.cbsnews.com/news/amanda-knoxs-parents-to-go-on-trial-in-perugia [http://perma.cc/6HDV-LJC6].

22. See Nancy J. King, How Different Is Death? Jury Sentencing in Capital and Non-Capital Cases Compared, 2 OHIO ST. J. CRIM. L. 195, 195 n.1 (2004) (noting that while "[a]ll jurisdictions 
imposes severe limitations on the sorts of evidence the state can present against the defendant. ${ }^{23}$ Even if the accused is a monster, we believe, he must be declared innocent if he did not commit the crime at issue; that means that the jury must be kept from hearing "prejudicial" facts about him if at all possible. ${ }^{24}$ Such facts may be considered during the sentencing phase ${ }^{25}$ - but only during the sentencing phase, after the defendant has been convicted and the jurors dismissed. Any deviation from this foundational evidentiary principle, Americans believe, will manifestly deny the defendant a fair trial, and will dangerously undermine the presumption of innocence. In America, we put people on trial for the crime with which they are charged, not for everything they have ever done. ${ }^{26}$ That seems to us a bedrock principle of civilized justice.

Yet inquisitorial procedure does not respect the bedrock distinction between guilt and sentencing phases! An inquisitorial trial serves both to determine guilt and to pass sentence in a single combined proceeding-and that means that character evidence relevant to sentencing gets aired in open court before the defendant has been formally adjudicated guilty. During the very opening minutes of a French or German trial, the presiding judge, to the dismay of Americans, questions the accused about the "course of his life before the crime with which he has been charged," while the jurors (in France) or the lay assessors (in Germany and Italy) look on. ${ }^{27}$ The

authorizing capital punishment bifurcate the capital trial," "[j]ury trials are bifurcated in five of the six states that authorize jury sentencing in non-capital cases").

23. See generally ROGER C. PARK ET AL., EVIDENCE LAW (3d ed. 2011) (describing the many evidence rules and exceptions that apply in American criminal and civil trials).

24. E.g., id. § 5.04, at 129 (explaining that the general ban on using evidence to establish a character trait is rooted in a fear that the evidence will be too prejudicial).

25. E.g., Chris William Sanchirico, Character Evidence and the Object of Trial, 101 ColuM. L. REV. 1227, 1268 (2001) (outlining what factors may be considered during sentencing, including evidence of "other crimes, wrongs, or acts").

26. Gerard E. Lynch, RICO: The Crime of Being a Criminal, Parts III \& IV, 87 CoLuM. L. REV. 920, 961-62 (1987).

27. Klaus Haller \& Klaus Conzen, Das Strafverfahren: Eine systematische DARSTELLUNG MIT ORIGINALAKTE UND FALLBEISPIELEN $\$$ 391-92, at 175-76 (7th ed. 2014) (Ger.) (advocating "Vernehmung des Angeklagten zur Sache, [interrogation of the accused as to the substance of the case,]" with "Erörterung des Vorlebens und persönlichen Werdegangs [consideration of past history and personal process]" and then "Angaben zum eigentlichen Tatgeschehen. [details of the actual crime.]" "Der Umfang der Vernehmung zur Person, also zum Lebensweg, richtet sich nach Umfang und Bedeutung des Anklagevorwurfs. Weist der Werdegang Auffälligkeiten auf-etwa pädophile Neigungen, psychiatrische oder psychotherapeutische Behandlungen-so gebietet es die Aufklärungspflicht, diesen Umständen nachzugehen. [The life course of the accused, focusing on the extent and seriousness of the accusation. If the personal history should show anomalies - such as paedophilic tendencies, psychiatric or psychotherapeutic treatments-the duty of disclosure dictates that these circumstances be taken into account]"); GASTON STÉFANI, GEORGES LEVASSEUR \& BERNARD BOUloc, Procédure PÉNAle $\S 860$, at 857 (22d ed. 2010) (Fr.) (describing the opening interrogation of the accused by the prosecutor as follows: "S'inspirant généralement de l'interrogatoire définitif auquel le juge d'instruction aura procédé, le président retrace la vie de 
courtroom revelations about the defendant may include a host of damaging and discreditable facts, such as that he plays hooky from school, ${ }^{28}$ skips out on work, ${ }^{29}$ drinks too much ${ }^{30}$ or has pedophilic tendencies. ${ }^{31}$ Meanwhile, there is at best limited respect for American practices of constitutional evidence suppression. ${ }^{32}$ In the Knox case, for example, the Italian lay assessors were permitted to hear the highly incriminating statement she had given to the police-even though that statement had been technically suppressed as a matter of Italian constitutional criminal procedure. ${ }^{33}$ American commentators were aghast. ${ }^{34}$ Nor do the inquisitorial countries have a tradition of vigorous cross-examination. There is nothing exactly like our confrontation clause jurisprudence in continental Europe, as our Supreme Court regularly asserts. ${ }^{35}$ Continental defense attorneys certainly

l'accusé jusqu'aux faits reprochés, et le déroulement de ceux-ci; il procède par voie de questions, mais l'accusé ne tient souvent qu'un rôle mineur dans ce dialogue. [Loosely following the formal interrogation conducted by the examining magistrate, the presider retraces the life of the accused before the alleged offences, and how they occurred; he proceeds by posing questions, but the accused often plays only a minor role in this dialogue.]").

28. Reinhard Granderath, Getilgt aber nicht vergessen: Das Verwertungsverbot des Bundeszentralregistergesetzes, 18 ZEITSCHRIFT FÜR RECHTSPOLITIK 319, 320 (1985) (Ger.) ("Schuleschwänzen, Weglaufen vom Arbeitsplatz, Vernachlässigung der Familie, fortgesetzter Alkholomißbrauch oder eine sonstige tadelnswerte Lebensfuhrung in Zumsammenhang mit der Tat. [Truancy, absconding from work, family neglect, continued alcohol abuse or other reprehensible lifestyles in connection with the crime.]").

29. Id.

30. Id.

31. HALLER \& CONZEN, supra note $27, \S 392$, at 176 . See also the accounts in DETLEV BURHOFF, HANDBUCH FÜR DIE STRAFRECHTLICHE HAUPTVERHANDLUNG 444-47 (5th ed. 2007) (prior convictions); id. at 921-28 (questioning of defendant); MiCHAEL HegHMANNS \& UwE SCHEFFLER, HANDBUCH ZUM STRAFVERFAHREN 673-78 (2008) (describing why a defendant would accept punishment silently when accused of alcoholism and other embarrassing characteristics).

32. For an introduction into the various factors that determine the admissibility of evidence, see the discussion of balancing in Gless, supra note 13, at 114. For a classic discussion, see Mirjan Damaška, Atomistic and Holistic Evaluation of Evidence: A Comparative View, in COMPARATIVE AND PRIVATE INTERNATIONAL LAW 91, 92 (David S. Clark ed., 1990).

33. The admission of her statement was possible because the Italian system, like other continental systems, permits the attachment of a civil suit to a criminal trial-in this case the civil defamation suit brought against Knox by Diya Lumumba, who was initially charged with the murder of Meredith Kercher on the strength of Knox's false statement. The procedural background is explained in Julia Grace Mirabella, Note, Scales of Justice: Assessing Italian Criminal Procedure Through the Amanda Knox Trial, 30 B.U. INT'L L.J. 229, 241-42 (2012).

34. Id.

35. See David Alan Sklansky, Anti-Inquisitorialism, 122 HARV. L. REV. 1634, 1650 (2009) (discussing the history of cross-examinations in England and America). But of course the question is far more complicated. Cf. Art. 111 Costituzione [Cost.] (It.) (affording the right to confront one's accuser); Convention for the Protection of Human Rights and Fundamental Freedoms art. 6, Nov. 4, 1950, 213 U.N.T.S. 221 (affording the same right). 
speak up on behalf of their clients, sometimes forcefully, but it is by no means unusual to see them conduct themselves in a deferential and even meek manner. ${ }^{36}$

Criminal procedure in Europe can involve wiretaps of conversations between lawyers and their clients; defamation prosecutions targeting critics of the police; defendants grilled in open court about their "course of life" before they have been found guilty; and reticent defense counsel. Encounters like these with contemporary continental justice leave Americans disoriented and uneasy; a trip to a continental courtroom is likely to reinforce the darkest suspicions that Americans harbor about the inquisitorial tradition-the sorts of suspicions that multiplied when Knox was initially convicted in a decision that seemed to put all the focus on her allegedly debauched "course of life" rather than on hard evidence of her guilt for the murder with which she was charged. ${ }^{37}$ The same sorts of suspicions have given rise to the spirit of "anti-inquisitorialism," in the words of David Sklansky, that increasingly pervades our Supreme Court jurisprudence on criminal procedure. ${ }^{38}$ Few Americans would conclude that contemporary continental countries are unbridled tyrannies of, say, the Fascist or Communist type. Certainly German or French justice does not seem as disturbing to Americans as justice in places like the Kyrgyz Republic, ${ }^{39}$ or Laos, ${ }^{40}$ or China. ${ }^{41}$ Nevertheless, from the American point of

36. For example, see the French documentary portraying a French murder trial, L'Affaire Delnatte, Justice en France (Le Cinq television broadcast June 12, 1991), https:// www.youtube.com/watch?v=u9ttUx-5tE [https://perma.cc/KL7Z-EKGH] (beginning at minute $11: 58)$ (Fr.).

37. See the fuller discussion in the Appendix, infra.

38. Sklansky, supra note 35 , at 1668 ("Anti-inquisitorialism is ... a broad and longstanding theme of American criminal procedure, and if anything it has grown more pronounced in recent years.").

39. See U.S. Dep'T OF STATE, BUREau of Democracy, Human Rights, and Labor, KYRGYZ REPUBLIC 2013 HUMAN RIGHTS REPORT 8 (2013), http://www.state.gov/documents/ organization/220607.pdf [http://perma.cc/4NAE-3YKW] ("While the law provides for defendants" rights, including the presumption of innocence, the government regularly violated these rights.").

40. See U.S. DEP'T OF STATE, BUREAU OF DEMOCRACY, HUMAN RIGHTS, AND LABOR, LAOS 5, http://www.state.gov/documents/organization/186495.pdf [http://perma.cc/S37X-KD9E] ("By law defendants enjoy a presumption of innocence, but in practice judges usually decided guilt or innocence in advance, basing their decisions on the result of police or prosecutorial investigation reports.").

41. E.g., Chris Buckley, China Aims to Abolish Goals for Arrests and Convictions, N.Y. TIMES (Jan. 21, 2015), http://www.nytimes.com/2015/01/22/world/asia/china-said-to-be-doing -away-with-goals-for-arrests-and-convictions.html [https://perma.cc/manage/vest/GV6P-97HK]; Andrew Jacobs \& Chris Buckley, Presumed Guilty in China's War on Corruption, Targets Suffer Abuses, N.Y. TIMES (Oct. 19, 2014), http:/www.nytimes.com/2014/10/20/world/asia/the-new -victims-of-chinas-war-on-corruption [http://perma.cc/GV6P-97HK] (reporting that an individual signed a confession after being beaten, starved, and interrogated for days). 
view the law of continental Europe does look suspiciously insensitive to some of the basic demands of justice, and at times perilously supine in the face of state investigative and prosecutorial power.

But if Americans shudder when they are exposed to continental practices, the same is true the other way around: We shock them too. Much of what shocks continental observers has to do with the American punishment system, which is often described in Europe as "barbarous." 42 Capital punishment is of course the most famous example of such American state "barbarism," but it is by no means the only one. American incarceration rates are, notoriously, the highest of any OECD countryhigher than in Russia and South Africa, both of which used to beat us out. ${ }^{43}$ Certainly they are spectacularly higher than the rates in Western Europe. ${ }^{44}$ Meanwhile, American prisoners benefit from few or none of the dignitary protections that are regarded as indispensable in Europe. ${ }^{45}$ You may enjoy more far-reaching evidentiary protections in an American courtroom than in a continental one, but once you are convicted, the American state is much more likely to condemn you to years, decades, or even life in a violent and degrading prison with limited hope of parole, or no hope at all.

Nor does continental shock end with the American punishment system. American criminal legislation and adjudication offend fundamental European principles as well. Take the example of strict and vicarious criminal liability. Continental criminal law rests on the rigorous application of the principle of personal responsibility: to continental Europeans, it

42. E.g., Marc Pitzke, Brutale Hinrichtungen: Immer mehr US-Bundesstaaten wollen Todesstrafe abschaffen, SPIEGEL ONLINE (Jan. 26, 2014, 1:31 PM) (Ger.), http://www.spiegel.de/ panorama/justiz/usa-bundesstaaten-schaffen-todesstrafe-nach-brutalen-hinrichtungen-ab-a-945270 .html [http://perma.cc/T75X-FV85]; Faustine Saint Géniès, Exécution en Oklahoma: "La peine de mort, c'est la barbarie" dénonce Badinter, PUB. SÉNAT (Apr. 30, 2014, 2:56 PM) (Fr.), http://www.publicsenat.fr/lcp/politique/execution-oklahoma-peine-mort-c-barbarie-denonce -badinter-562877 [https://perma.cc/5X9J-HHXU]; Maximilian Steinbeis, USA: Lebenslang für Jugendliche-Ende einer barbarischen Strafrechtspraxis?, VERFASSUNGSBLOG ON MATTERS CONSTITUTIONAL (Nov. 9, 2009) (Ger.), http://www.verfassungsblog.de/usa-lebenslang-fur -jugendliche-ende-einer-barbarischen-strafrechtspraxis/\#.Vkj0g9-rSu5 [http://perma.cc/7QN6 -7MA5] (for a practice now abandoned after Miller v. Alabama, 132 S. Ct. 2455 (2012), which held that mandatory life imprisonment without parole for those under the age of eighteen at the time of their crime violates the Eighth Amendment).

43. Michael Tonry, Crime and Criminal Justice, in THE OXFORD HANDBOOK OF CRIME AND CRIMINAL Justice 3, 17-19 (Michael Tonry ed., 2011).

44. See, e.g., Highest to Lowest - Prison Population Rate, WORLD PrISON BRIEF, http://www.prisonstudies.org/highest-to-lowest/prison_population_rate?field_region_taxonomy _tid=22 [http://perma.cc/FGL2-42EA] (showing comparative figures by country).

45. JAMES Q. WHITMAN, HARSH JUSTICE: CRIMINAL PUNISHMENT AND THE WIDENING DIVIDE BETWEEN AMERICA AND EUROPE 9 (2003). 
seems elementary that in a civilized country offenders can only be criminally convicted for acts they themselves have committed with a culpable state of mind. ${ }^{46}$ That, they would say, is a bedrock principle of civilized justice. ${ }^{47}$

Yet American criminal law is rife with doctrines of strict and vicarious liability, notably in areas like the law of felony murder and conspiracy, and those doctrines are energetically exploited by American prosecutors ${ }^{48}$ (and sententiously endorsed by American judges ${ }^{49}$ ). In America you can be punished for an act you had no culpable intention of committing, for harm that you had no culpable intention of causing, or even for an act committed by someone else. ${ }^{50}$ When Europeans learn about these American doctrines and practices, they see, once again, barbarism. ${ }^{51}$ How can any civilized

46. StRAFGeSETZBUCH [STGB] [PENAL CODE], \& 15 (Ger.), translation at https://www .gesetze-im-internet.de/englisch_stgb/german_criminal_code.pdf [https://perma.cc/8P9J-KZ46] ("Strafbar ist nur vorsätzliches Handeln, wenn nicht das Gesetz fahrlässiges Handeln ausdrücklich mit Strafe bedroht. [Unless the law expressly provides for criminal liability based on negligence, only intentional conduct shall give rise criminal liability.]"); see also KRISTIAN KÜHL, STRAFRECHT: ALLGEMEINER TEIL 78-79 (4th ed. 2002) (Ger.) (discussing StGB § 15); WALTER GROPP, STRAFRECHT: ALLGEMEINER TEIL 67-69 (3d ed. 2005) (Ger.) (basing discussion on human dignity). For the French perspective, see JEAN PRADEL, MANUEL DE DROIT PÉNAL GÉnÉral 461-62 (15th ed. 2004); Line Teillot \& PasCale Urbansky, Droit PÉNal GÉNÉRAL 76-77 (2008) (Fr.).

47. See James Gordley, Responsibility in Crime, Tort, and Contract for the Unforeseeable Consequences of an Intentional Wrong: A Once and Future Rule?, in THE LAW OF OBLIGATIONS 175, 176 (Peter Cane \& Jane Stapleton eds., 1998) (contrasting Italian and American responses to rules in their own bodies of law holding defendants liable for some acts they had not intended to commit).

48. Darryl K. Brown, Criminal Law Reform and the Persistence of Strict Liability, 62 DUKE L.J. 285, 332 (2012) (observing that incarceration rates between the United States and Europe had roughly tracked one another through the 1960 s, but that American rates approximately quintupled in the period between the 1970s and the 2000s); Alex Kreit, Vicarious Criminal Liability and the Constitutional Dimensions of Pinkerton, 57 AM. U. L. REV. 585, 598 (2008) (noting American prosecutors' increasing use of Pinkerton liability beginning in the 1970s).

49. See Brown, supra note 48 , at 324-25 (finding that the rationale judges regularly invoke for strict liability interpretations is the idea that no proof of culpability is required beyond that needed to ensure that an actor is not convicted for purely innocent conduct); see also Andrew Ashworth \& Meredith Blake, The Presumption of Innocence in English Criminal Law, 1996 CRIM. L. REV. 306, 316-17 (discussing the connection between strict liability and the burden of proof).

50. See Pinkerton v. United States, 328 U.S. 640, 646-47 (1946) (upholding the conviction of the defendant for acts of a coconspirator made in furtherance of the conspiracy); GUYORA BINDER, FELONY MURDER 28 (2012) ("[A] felony murder law is simply a law conditioning murder liability on unintended killing in the commission or attempt of a felony."). The absence of conspiracy law in non-common law, and especially non-American common law, traditions came to the fore most recently in Hamdan v. Rumsfeld, 548 U.S. 557, 566 (2006). The American tendency to use conspiracy law as a means of dealing with terrorism creates serious tension on the international scene.

51. Jean PRADEL, DRoIT PÉNal COMParé 95 (3d ed. 2008) (objecting to felony murder doctrine); Gordley, supra note 47, at 175-83; Katja Gelinsky, Jeden Tag eine böse Tat, FRANKFURTER ALLGEMEINE (Dec. 5, 2009) (Ger.), http://www.faz.net/aktuell/wirtschaft wirtschaftspolitik/amerikanisches-strafrecht-jeden-tag-eine-boese-tat-1899813.html 
society punish one person for an act committed by another? Here it is the Europeans who shudder. As we shall see, there are other examples of American doctrines that shock the continental conscience.

Even the guarantees of American criminal trial seem patently inadequate to continental jurists. Europeans insist that any person charged with an offense carrying a serious penalty must be afforded a trial. ${ }^{52}$ Doing so seems to them a minimum requirement of a just order. Americans, by contrast, tolerate a system in which even life imprisonment may be imposed as the result of a mere plea bargain, and in which full-scale trials have become vanishingly rare events. ${ }^{53}$

So from either shore we gaze across the Atlantic in dismay (and no doubt self-satisfaction). How did it come to pass that conceptions of fundamental justice differ so much in countries that share such a deep commitment to curbing abuses of state power and that share so much of their Western cultural heritage as well?

\section{Presumption of Innocence/Presumption of Mercy}

Our standard comparative law literature has no satisfying answer to give. The literature commonly takes a familiar line in describing the contrast between them and us: the fundamental tension at work, our literature explains, is the tension between the protection of rights and the pursuit of the truth. The American adversarial system puts the emphasis on due process rights, suppressing and excluding evidence even at the cost of having "trials without truth." ${ }^{54}$ The Europeans, by contrast, are reluctant to

[http://perma.cc/UG5C-CXCY] (describing American strict liability offenses); Bastian Fresca, Leser-Kommentar, Felony Murder Rule?, FocUs (Apr. 14, 2014, 7:04 PM) (Ger.), http://www.focus.de/panorama/welt/felony-murder-rule-harsche-us-rechtsprechung-kommentar id 5703638.html [http://perma.cc/X4X4-N383] (confused account with denunciation of Americans as "barbarians"); $c f$. DENIS SALAS, LA VOLONTÉ DE PUNIR: ESSAI SUR LE POPULISME PÉNAL 118-20 (2005) (arguing that irrational dangerousness calculus has swamped mens rea focus in American criminal justice). It is important to observe that the law of complicity presents complications that open the possibility of various forms of vicarious liability in all systems. For French conspiracy law, see, for example, CODE PÉNAL [C. PÉN.] art. 121-7 (Fr.), translation at https://www.legifrance.gouv.fr/content/download/1957/13715/version/4/file/Code_33.pdf

[https://perma.cc/Y4TB-EL32]. Nevertheless, as the French observe, the French sentencing regime leaves ample room for distinguishing accomplices from principals. Still, close study of the application of the law of complicity might reveal more continental willingness to countenance forms of strict and vicarious liability in practice than continental authorities are prepared to acknowledge. Indeed, as I will suggest below, continental practices permit means of dealing sub rosa with questions of dangerousness that are effectively dealt with in the United States through doctrines of strict and vicarious liability.

52. See infra notes 56-58 and accompanying text.

53. U.S. DEP'T OF JUSTICE, BUREAU OF Justice ASSISTANCE, Plea AND Charge BARGAINING: RESEARCH SUMMARY 1 (2011), https://www.bja.gov/Publications/ PleaBargainingResearchSummary.pdf [https://perma.cc/9KWB-EEZ8] (noting that of the 75,573 cases disposed of in federal district court by trial or plea, $95 \%$ were disposed of by a guilty plea).

54. William T. Pizzi, TRials Without TruTH 25 (1999). 
sacrifice investigative fact-finding efficiency on the altar of rights; they believe too deeply in the imperative of establishing the whole truth for that. Europeans insist on an inquiry into the whole truth: that is why they are called "inquisitorial" while we are called "adversarial." 55 (There is another, more philosophically abstract version of the argument as well: the common law tradition, scholars sometimes say, has a history of treating defendants as subjects, the bearers of rights; whereas the continental tradition has a history of treating them as mere objects. $)^{56}$ For most commentators, the implication is that inquisitorial Europeans have lessons to learn from the adversarial Americans about protecting the due process rights of the accused - though for some, the implication is that Americans should learn from the Europeans to take off the investigative gloves. ${ }^{57}$

That familiar account of the differences between inquisitorial and adversarial values is certainly not completely off base. It is indeed the case, for the most part, ${ }^{58}$ that continental systems are more rigorously committed to getting to the truth through professional investigative techniques, and accordingly less solicitous of American-style due process rights. Nevertheless, focusing on the tension between truth-seeking and rightsprotection is by no means sufficient. Yes, the Europeans want to get the whole truth. But it would be deeply mistaken to imagine that they care only about fact-finding efficiency and not about rights. The Europeans most certainly do care about rights. If they did not care about rights, they would not be shocked by the aspects of American justice that shock them. What matters is that their understanding of the rights at stake is different from ours.

55. See Thaman, supra note 12, at 248 (contrasting the inquisitorial "search for the truth" with the rights alternative associated with the adversarial tradition).

56. See, e.g., 1 Julio B. J. MAIER, DEREChO PROCESAL PENAL 314-15 (2d ed. 2004) (Spain) (discussing impact of a 1670 French ordinance on the development of continental tradition).

57. For a discussion of the classic rights versus truth account of Comparative Criminal Procedure, including a welcome expression of skepticism, see generally Máximo Langer \& Kent Roach, Rights in the Criminal Process: A Case Study of Convergence and Disclosure Rights, in ROUTLEDGE HANDBOOK OF CONSTITUTIONAL LAW 273 (Mark Tushnet et al. eds., 2013). It is important to see this interpretive tradition in comparative law in its historical context. The idealization of common law rights extends back to the anglomanie of the eighteenth century, and in some sense as far back as Fortescue. Nevertheless, the modern American literature took shape against the background of American debates over the due process revolution, with the result that scholars tended to interpret the contrast between our system and the European alternatives as a contrast between a due process order and a less hampered investigative order. The most important figure in this regard is John Langbein, whose critique of the complexity of due-process-oriented American trials can be found, for example, in John H. Langbein, Land Without Plea-Bargaining: How the Germans Do It, 78 MICH. L. REV. 204, 206 (1979). For a brilliant classic precursor, see JAMES FITZJAMES STEPHEN, A GENERAL VIEW OF THE CRIMINAL LAW OF ENGLAND 166 (K.J.M. Smith ed., Oxford Univ. Press 2014) (1863) ("[T]he inquisitorial theory of criminal procedure is beyond all question the true one. It is self-evident that a trial ought to be a public inquiry into the truth of a matter....").

58. But see infra note 211 and accompanying text. 
We need an account that focuses squarely on how our conceptions of rights differ, and that is what this Article aims to offer. Our conceptions of rights differ, it aims to show, in ways that must be seen against the background of the contrast between two cultural orientations in criminal law: on the one hand, an orientation toward our familiar presumption of innocence, focused on the rights of the innocent; on the other hand, an orientation toward what I propose to call the "presumption of mercy," focused on the rights of the guilty.

The phrase "presumption of mercy" is certainly unfamiliar. Existing legal systems do not use it; it is my own invention. Readers may object that it is wrong to describe European systems with a phrase that Europeans do not use themselves. ${ }^{59}$ Nevertheless, I am convinced that a great deal of what we find mutually shocking can best be understood if we recognize the value of this admittedly unfamiliar legal concept. More than that, I believe that it can help us gain insight into some dilemmas of modern criminal justice everywhere.

Since the concept "presumption of mercy" is unfamiliar, though, a few preliminary clarifications are in order. First, it is important to dispel one natural misunderstanding: A system oriented toward a presumption of mercy is not a system that refuses to punish. A presumption of mercy is simply a presumption - a presumption that offenders will be spared, or subjected to milder punishment, if appropriate. All presumptions can be overcome, and that is true of this one as well. The presumption of mercy does not bar punishing the guilty any more than the presumption of innocence bars convicting the accused. It simply forces justice officials to work hard in order to justify the decision to punish, just as the presumption of innocence is designed to force justice officials to work hard in order to justify the decision to convict; and once the presumption of mercy is overcome, the criminal justice system may well impose tough sentences. Both orientations create presumptions for the same reason: imposing criminal punishment is a morally fraught business, which tests our conscience. We have a deep fear of making mistakes, and so we create

59. The methodological questions are important-though I think not important enough to merit sustained discussion in the text. It is true that "presumption of mercy" is not only unknown in European law, but difficult to render in European languages. (The best choice may be Latin: praesumptio clementiae as contrasted with praesumptio innocentiae; this would yield the French présomption de clémence/présomption d'innocence. It is not easy to construct a corollary for the German Unschuldsvermutung; perhaps one could revive the expression Gnadengebot). If our task is simply to give a faithful account of how foreign systems are understood by those who operate within them, this Article is a misguided enterprise. Nevertheless, I resist that view of our task, even in the compelling version presented by William Ewald, Comparative Jurisprudence (I): What Was It Like to Try a Rat, 143 U. PA. L. REV. 1889 (1995). I think that it is possible to grasp dynamics of the law in ways that depart from familiar descriptions, but that are nevertheless revealing. Readers, European and American, will have to judge for themselves whether the Article succeeds in the effort. 
procedural presumptions that will force us to justify our decisions with care and suitable deliberation. But the two orientations conceive of the risks of mistake attendant on criminal punishment differently. The first kind of presumption is designed to counter the risk that we will sin by inflicting punishment on those who are in fact innocent, while the second is designed to counter the risk that we will sin by mistreating those who are in fact guilty.

Second, the contrast that I wish to sketch out is not just a contrast between two technical rules. It is the contrast between two larger cultural orientations in the law. American cultural allegiance to the presumption of innocence extends beyond the technical courtroom rule putting the burden of proof on the state. "[O]ur generally accepted ideology of a presumption of innocence, ${ }^{, 60}$ to repeat Packer's phrase, shapes American legal culture much more broadly than that: We share an almost instinctive orientation that rests on the belief that the most serious threat to justice is the threat that the innocent will be targeted. ${ }^{61}$ The impact of that orientation is felt throughout American criminal law, not just in courtroom respect for the technical presumption of innocence. ${ }^{62}$

In much the same way, the orientation toward the presumption of mercy extends beyond technical rules requiring mitigation of punishment. It belongs to a much broader continental cultural pattern whose sources lie ultimately in a hierarchical, paternalistic understanding of justice. Mirjan Damaška famously argued that continental justice assumes a hierarchical structure of authority; ${ }^{63}$ we see just such a structure of authority in the strong continental orientation toward mercy: In line with the hierarchical sensibility, continental legal practices rest broadly on the belief that justice officials have a "paternalistic obligation to protect the defendant."

Third, when I say that the clash between our legal cultures ought to be seen against the background of the dichotomy between these two contrasting orientations, I do not mean that there is some simple equation to be drawn between American law and the culture of the presumption of innocence, or between continental law and the culture of the presumption of mercy. It is not the case that American criminal justice turns exclusively on the presumption of innocence, nor that the continental traditions turn exclusively on the presumption of mercy. All the legal cultures of the

60. Packer, supra note 1, at 11 .

61. Id.

62. PIZZI, supra note 54, at 46-68 (surveying the evidentiary hurdles that American prosecutors have to cope with when attempting to bring a case against a criminally accused individual).

63. Mirjan Damaška, Structures of Authority and Comparative Criminal Procedure, 84 YALE L.J. 480, 487 (1975).

64. William T. Pizzi \& Mariangela Montagna, The Battle to Establish an Adversarial Trial System in Italy, 25 MICH. J. INT'L L. 429, 449 (2004). 
Atlantic world are products of complex histories in which the two threads are interwoven. The continental traditions, in particular, most certainly do include a presumption of innocence. My aim is only to show that the presumption of mercy stands out much more prominently in the fabric of modern day continental justice. There is no necessary absolute choice between either the presumption of innocence or the presumption of mercy; but it is the case that the presumption of mercy has proven more at home in the continental world.

Nor is that surprising: for as I will emphasize, fourthly, the two orientations are rooted in different political sensibilities. Indeed, it is essential that we recognize that the two presumptions are at home in two different political cultures. The presumption of innocence fits comfortably within an antistatist, classic liberal sensibility of the kind we so often encounter in American law. By contrast, the presumption of mercy fits more comfortably within a statist sensibility, informed by deference to the authority and expertise of government officials.

It is nothing new to say that differences in political culture lie in the background of our differences in criminal procedure: in particular, it is a commonplace that the relative passivity of the common law judge and the relative autonomy of the common law jury reflect traditions of common law resistance to strong assertions of government authority. ${ }^{65}$ But it is important to recognize that the importance of political culture extends beyond these well-worn questions of the power of judge and jury. Political culture also has a fundamental impact on the understanding of a basic problem in criminal law analysis that is centrally important for this Article: how to decide which offenders to classify as "innocent."

Innocence is, after all, not a self-explanatory concept. There is more than one way of determining which defendants should count as "innocent." In particular, when we have deserving offenders before us-those who have some excuse or justification to offer in their defense-we can choose to deem them either "innocent" or "guilty but forgiven"; we can opt either for exculpation or for mercy. For example, if individuals kill in self-defense, we can opt either to acquit them (as is the case in modern Western systems ${ }^{66}$ ), or to convict them but then pardon them (as was frequently the case in earlier centuries ${ }^{67}$ ).

65. For an example, with reference to the Knox case, see Mirabella, supra note 33, at 250-51.

66. C. PÉN., supra note 51, art. 122-5 (Fr.); STGB, supra note 46, § 32 (Ger.).

67. See 4 WILlIAM BLACKSTONE, COMMENTARIES *184 (observing that where a killing was the result of self-defense, a general verdict of acquittal was usually permitted by English judges of the time); NAOMI HURNARD, THE KING'S PARDON FOR HOMICIDE BEFORE A.D. 1307, at 1 (1969) (discussing the king's authority to grant pardons in the Anglo-Saxon era); Elizabeth Papp Kamali, A Felonious State of Mind: Mens Rea in Thirteenth- and Fourteenth-Century England 1 (2015) (unpublished Ph.D. dissertation, University of Michigan) (on file with Texas Law Review) (noting that under twelfth-century English law, a homicide judgment often allowed jurors to decide 
It should be obvious that the choice we make between these two options has significant implications for the place of criminal justice within the larger political order of a given society. Mercy, the practice of declaring offenders "guilty but forgiven," is closely associated with assertions of strong state authority. Thus monarchical systems of justice always made heavy use of discretionary royal mercy before the nineteenth century and continue to make heavy use of mercy today. The Thai and Saudi monarchies, for example, make ostentatious use of pardons. ${ }^{68}$ For that matter, the Nazis did too. (For example, there was a general amnesty for low-level offenders on the occasion of Hitler's birthday. ${ }^{69}$ States that claim extensive authority often maintain that authority in part through displays of mercy.

By contrast, exculpation - the practice of declaring deserving offenders "innocent"-comports with an antistatist approach to criminal justice. If we declare our deserving offenders "innocent," we declare them to be immune as a matter of principle to the state's punishment power, regardless of whether the state chooses to punish or pardon. Correspondingly, when lawyers and legislators develop doctrines of exculpation that permit verdicts of "innocent," they are doing more than just exploring the dictates of moral philosophy, as most professors of criminal law like to think of themselves as doing. They are engaging in a form of juristic politics, erecting tacit doctrinal barriers against the assertion of state power.

It should be clear that opting for exculpation rather than mercy is in deep harmony with an orientation toward the presumption of innocence. If we declare the class of deserving offenders "innocent" rather than "guilty but forgiven," we bias the system in favor of finding more defendants technically "innocent." We create, not precisely a presumption of innocence, but a kindred bias toward verdicts of innocence. Choosing to declare deserving offenders "guilty but forgiven," by contrast, is obviously more in tune with the presumption of mercy. Instead of swelling the ranks of those who will be deemed "innocent," it puts the focus on the question of whether it is right to go easy on some of those found "guilty" or, conversely, right to subject some of them to stiffer sentences because they represent more of a danger to society.

whether to "send an accused man or woman back to prison to await a pardon, into the world as a free individual, or to the gallows").

68. 500 Prisoners Benefit from Royal Pardon, ARAB NEws (June 28, 2014, 2:11 AM), http:/www.arabnews.com/news/593446 [http://perma.cc/5MJR-MDQV]. The Thai practice of pardoning is especially common, and noteworthy, in cases involving insults to the monarchy. See, e.g., Thai King Pardons American Convicted of Insulting Monarchy, GUARDIAN (July 10, 2012, 11:30 PM), http://www.theguardian.com/world/2012/jul/11/thai-king-pardons-american-insulting [http://perma.cc/3FJF-LT2S].

69. WHITMAN, supra note 45 , at 148 . 
Of these two, mercy is inevitably more difficult for Americans to accept than exculpation, since it assumes the legitimacy and superior wisdom of paternalistic state officials in a way against which they tend to rebel. As a result, it can be hard for us to swallow the lessons we ought to learn from the continental traditions. ${ }^{70}$ Nevertheless, they are lessons we must swallow. For if we can overcome our shock and acquire a better appreciation of the values of continental justice, we will also acquire a healthy sense of the dangers in our own approach-dangers that are grave, growing, and too easily neglected by Americans too attached to the idea that the most urgent danger we face is the danger that a malevolent or outof-control state will target citizens who are in fact innocent.

\section{Beyond the American Presumption of Innocence}

Nobody is likely to be surprised when I say that the American approach to limiting state power corresponds much more to the mode of justice oriented toward the presumption of innocence than the mode oriented toward the presumption of mercy. We all recognize that American justice revolves around Packer's "generally accepted ideology of a presumption of innocence" ${ }^{\text {"71 }}$ : it is a frequently repeated American truism that " $[t]$ he wrongful conviction of an innocent person is the worst nightmare to anyone who cares about justice."72 ("Nightmare" is indeed a regularly incanted word.) $)^{73}$ It is also a touchstone of American Human Rights policy that violations of the presumption of innocence are capital instances of political injustice throughout the world. ${ }^{74}$

Not least, it is a commonplace that the "nightmare" of the conviction of the innocent is a real and pressing danger in America itself. Americans are used to worrying that state investigators may be biased, overweening,

70. For expressions of American hostility to mercy, see an article by the late Dan Markel: Against Mercy, 88 MINN. L. REV. 1421, 1422, 1478-79 (2004), and Robinson, supra note 6. One is inclined to cry out in response, with Camille Desmoulins, "[P]ourquoi la clémence seroit-elle devenue un crime dans la République? [Why has mercy become a crime in the Republic?]" CAMIlle Desmoulins, Le ViEUX CORDELIER 124 (Albert Mathiez eds., 1936) (Fr.).

71. Packer, supra note 1, at 11.

72. H. Patrick Furman, Wrongful Convictions and the Accuracy of the Criminal Justice System, COLO. LAW., Sept. 2003, at 11, 11.

73. See, e.g., BRANDON L. GARRETT, CONVICTING THE INNOCENT: WHERE CRIMTNAL PROSECUTIONS Go WRONG 243 (2011) (quoting North Carolina Governor Mike Easley asserting that an innocent person in jail is law enforcement's "greatest nightmare").

74. See WHITMAN, supra note 45, at 77-78 (explaining how Americans generally view "investigatory custody," which allows investigating magistrates to hold suspects for extended periods of time with few procedural checks, as unfair, harsh, and nearly tyrannical). 
indifferent to our privacy interests, racist, or at the very least dangerously incompetent; while the jury, which is supposed to serve as our bulwark against state malfeasance, may all too easily be manipulated by the adversarial prosecutors determined to win cases. ${ }^{75}$

And Americans may well be right to worry. It is undoubtedly the case that the overwhelming bulk of accused persons in America are guilty; most cops and most prosecutors are decent people doing their best at tough jobs; and in the vast majority of cases that result in charges, it is perfectly obvious who the culprit is. Nevertheless, it is a fair guess that more innocents are convicted in America than in continental Europe. That is the implication of work like Brandon Garrett's 2011 book Convicting the Innocent, which reconstructs how more than two hundred American defendants whose innocence was later proved through DNA evidence were initially convicted. ${ }^{76}$ Our underprofessionalized, politicized, procedurally haphazard system, so effectively described by Garrett, almost certainly produces more wrongful convictions than the more highly professionalized and non-adversarial continental systems do. ${ }^{77}$ (There are also doctrinal reasons why the common law, and in particular the American common law, lends itself to wrongful convictions more than continental law does.) ${ }^{78}$ For those reasons alone, it is understandable that the presumption of innocence should feature peculiarly prominently in the American idea of justice.

There is another reason as well: roughly $95 \%$ of American cases are resolved by plea bargain. ${ }^{79}$ The inevitable consequence is that the tiny percentage of cases that go to trial involve a heavy disproportion of

75. See generally, e.g., Victor Gold, Psychological Manipulation in the Courtroom, 66 NEB. L. REV. 562 (1987) (discussing how evidence can be manipulated to affect the jury's perception and the ultimate outcome of the case).

76. See generally GARRETT, supra note 73. Other work in the same vein is surveyed in Christopher Slobogin, Lessons from Inquisitorialism, 87 S. CAL. L. REV. 699, 704-06 (2014).

77. Our "trust in the [common law] trial process," as Garrett delicately concludes, "may have been misplaced." GARRETT, supra note 73 , at 260 . For the contrast with the continental tradition of fact-finding, with its repeated vetting of the dossier, see the discussion in Part V, infra.

78. We know that wrongful convictions are very frequently the result of false confessions. Yet in the continental world, a confession uncorroborated by other evidence is insufficient to sustain a conviction. See the discussion in Lissa Griffin, Can "Real" Corroboration Requirements Prevent Wrongful Convictions?, COMP. L. PROF BLOG (Mar. 28, 2014), http:/lawprofessors.typepad.com/comparative_law/2014/03/can-real-corroboration-requirementsprevent-wrongful-convictions.html [http://perma.cc/5XQA-JYED]. Historically the common law used the corpus delicti rule, which required at least hard evidence that the crime to which the defendant had confessed had in fact been committed; but even the corpus delicti rule has been generally abandoned in the United States. For a recent example, see the Etan Patz case. James C. McKinley Jr., Confession in Etan Patz Case Can Be Used at Trial, Judge Rules, N.Y. TIMES (Nov. 24, 2014), http://www.nytimes.com/2014/11/25/nyregion/confession-in-etan-patz-case-canbe-used-at-trial-judge-rules.html [http://perma.cc/6MHN-WDB9]. Given all we know about false confessions, this is a reprehensible development.

79. U.S. DEP'T OF JUSTICE, BUREAU OF JUSTICE ASSISTANCE, supra note 53, at 1. 
defendants with colorable claims of innocence. ${ }^{80}$ Anybody whose understanding of the nature of criminal justice is formed by witnessing trial in modern America will naturally conclude that innocent persons are frequently accused.

For those reasons, and because the presumption of innocence fits so comfortably within an antistatist, classic liberal sensibility, it is unsurprising that the American idea of justice revolves heavily around the presumption of innocence. We fear, understandably, that evils will transpire in the American investigative process; we share a cultural sensibility that imagines that the state is out to get us; and, committed to forestalling the conviction of the innocent and more broadly to preserving liberty, we agree-on both the American left and the American right-that we must make it difficult for the state to prove its case and difficult for the state to blacken the jury's perception of the defendant. ${ }^{81}$

In particular, we embrace Packer's "obstacle course" model of due process. ${ }^{82}$ The core institutions for limiting state power, on this American "obstacle course" understanding, have to do with evidence: they are the Fourth Amendment, permitting the suppression of illegally gathered evidence, and the admissibility rules of trial evidence, permitting the exclusion of all that might be prejudicial. ${ }^{83}$ The "obstacle course" also includes other practices intended to combat the risk of juror prejudice, such as elaborate voir dire and the occasional transfer of a highly publicized case to a less prejudicial venue. ${ }^{84}$ This American system has plenty of critics and skeptics. But by and large it commands tremendous support. Our culture of the presumption of innocence seems to Americans, left and right, one of the glories of our tradition of safeguarding civil liberties, celebrated in Supreme Court opinions and television shows alike. ${ }^{85}$ Our concern with

80. Consider the analogous result in the civil context. Cf. George Priest \& Benjamin Klein, The Selection of Disputes for Litigation, 13 J. LEGAL STUD. 1, 1-6 (1984) (explaining that in the civil context, cases that go to trial are the ones in which the verdict is difficult to predict).

81. See Packer, supra note 1, at 14-15 (outlining a model of criminal process that stresses the possibility of error, insists on formal adjudicative fact-finding, and rejects efficiency in favor of increased protection for the factually innocent).

82. Packer, supra note 1 , at 13.

83. See Mark E. Cammack, The Rise and Fall of the Constitutional Exclusionary Rule in the United States, 58 AM. J. COMP. L. 631, 632-33 (2010) (discussing the function of the exclusionary rule regarding the Fourth, Fifth, and Sixth Amendments); infra notes 122-25 and accompanying text on the law of evidence.

84. Voir dire of the American kind is unknown in Europe. For the selection of jurors in France, see, for example, MICHĖlE-LAURE RASSAT, TRAITÉ DE PROCÉDURE PÉNALE 118-20 (2001) (Fr.) (outlining the jury selection process in France).

85. See, e.g., Coffin v. United States, 156 U.S. 432, 453 (1895) ("The principle that there is a presumption of innocence in favor of the accused is the undoubted law, axiomatic and elementary, and its enforcement lies at the foundation of the administration of our criminal law."). 
the fate of innocents who are unjustly targeted looms as large in Hollywood as it does in the law, and it pervaded American reactions to the Amanda Knox case. ${ }^{86}$

But our concerns are emphatically concerns for the innocent. Once an American defendant has been properly convicted, and consigned to the class of the guilty, American law affords startlingly few protections-few limits on proportionality in punishment, few mechanisms for intervening in the management of prisons, few rights of reintegration after release. ${ }^{87}$ Nor is it only our law that turns on protections for the innocent. The same is true of our political culture. There is growing opposition to the death penalty in America, for example. ${ }^{88}$ But it is opposition predicated primarily on the fear that innocent persons might be executed, not on the idea, common in Europe, that there might be something wrong about execution as such. ${ }^{89}$ Our fundamental concerns are concerns for the innocent, not the guilty, who seem to us to have forfeited their rights by committing an act prohibited by a law passed through proper democratic processes. There is a deep-seated tendency in America to regard "offenders who break the social contract and violate our criminal laws" protections that law-abiding citizens are entitled to expect. ${ }^{\text {I1 }}$

This American "ideology of a presumption of innocence" does not reign in the continental countries. This is not, let me rush to say, because the inquisitorial tradition does not have its own version of the presumption of innocence. It does. In fact, the continental commitment to the presumption of innocence is much older than ours: proudly though Americans may celebrate the presumption of innocence today, the truth is that it was formally endorsed by the American Supreme Court only in $1895 .^{92}$ On the Continent, by contrast, the presumption of innocence can be traced back deep into the Middle Ages: "every person must be presumed

86. Mirabella, supra note 33 , at 231.

87. I have surveyed many of the differences between American and continental European practice in Harsh Justice. The issues include felon disenfranchisement (essentially unknown in Europe) and the European right to privacy and protection for personality, which are intended to allow convicts to reintegrate themselves in society despite a criminal conviction. See WHITMAN, supra note 45 , at 84-92.

88. Less Support for Death Penalty, Especially Among Democrats, PEW RES. CTR. (Apr. 16, 2015), http://www.people-press.org/2015/04/16/less-support-for-death-penalty-especially-among -democrats/ [https://perma.cc/KD7L-JZWG].

89. See generally Carol S. Steiker \& Jordan M. Steiker, The Seduction of Innocence: The Attraction and Limitations of the Focus on Innocence in Capital Punishment Law and Advocacy, 95 J. CRIM. L. \& CRIMINOLOGY 587 (2005) (articulating various concerns with the prominence of innocence in arguments to abolish the death penalty).

90. People v. Saetern, 174 Cal. Rptr. 3d 836, 846 (2014).

91. For the classic, and highly influential, modem American philosophical elaboration of this social-contractarian intuition, see Herbert Morris, Persons and Punishment, 52 MONIST 475, 477 (1968).

92. Coffin v. United States, 156 U.S. 432, 452-53 (1895). 
innocent until proven guilty" was a formula originally coined, around 1300 , not by a common lawyer, but by a continental one. ${ }^{93}$ There has been a continuous and often vigorous continental jurisprudence of the presumption of innocence ever since. ${ }^{94}$

Nevertheless there is no doubt that the continental presumption of innocence is conceived differently from ours. In part, this is because continental protections for privacy are conceived differently. In both the American and the continental traditions, the presumption of innocence is regarded as basic to the protection of privacy. But (as I have argued at length elsewhere) $)^{95}$ Americans tend to think of privacy as a liberty interest, primarily threatened by the government. Continentals, by contrast, tend to think of privacy as a dignity interest, primarily threatened by public exposure in the media. ${ }^{96}$ That difference has a direct impact on their understanding of how the innocent should be protected. Americans think of the privacy interest at stake as an interest in being shielded against government investigators. ${ }^{97}$ The Europeans, by contrast, think that accused persons should be shielded from exposure in the media as well. ${ }^{98}$ Thus they regard American practices like the "perp walk" and the casual publication of the names of suspects as truly shocking violations of the presumption of innocence. (The treatment of Dominique Strauss-Kahn at the hands of the New York police is the most recent example: After he was subjected to the perp walk, there were howls of protest in the press of all the Western European countries. ${ }^{99}$ Is there no presumption of innocence in America? asked European observers.) $)^{100}$

93. Kenneth Pennington, Innocent Until Proven Guilty: The Origins of a Legal Maxim, 63 JURIST 106, 109, 112 (2003). The formula is generally traced to French canonist Jean Lemoine, known amongst the cardinals as Johannes Monachus (1250-1313). Id. at $116 \mathrm{n} .26$; see also Kenneth Pennington, Due Process, Community, and the Prince in the Evolution of the Ordo Iudiciarius, 9 RIVISTA INTERNAZIONALE DI DIRITTO COMMUNE 9, 36 n.90 (1998) ("Johannes Monachus to Extrav. Com. 2.3.1: 'Item quilibet presumitur innocens nisi probetur nocens, extra. de presum. c. Dudum (X 2.23.16), extra. de scrut. in ord. fac. c. unico (X 1.12.1), ff. de manumis. test. I. Seruos (D.40.4.20) et ius est promptius ad absoluendum quam ad condemnandum.' [A person is presumed innocent until proven guilty. [X 2.23.16; X 1.12.1; D.40.4.20] And the law is quicker to absolve than to condemn.]").

94. The early history is associated in particular with the maxim "in dubio pro reo"-_."when in doubt, for the accused." E.g., PETER HOLTAPPELS, DIE ENTWICKLUNGSGESCHICHTE DES GRUNDSATZES “IN DUBIO PRO REO" 1-6(1965); see also DECLARATION OF THE RIGHTS OF MAN AND THE CITIZEN art. 9 (1789) (Fr.); G.A. Res. 217 (III)A, Universal Declaration of Human Rights, art. 11 (Dec. 10, 1948).

95. See generally James Q. Whitman, The Two Western Cultures of Privacy: Dignity Versus Liberty, 113 YALE L.J. 1151 (2004).

96. Id. at $1160-62$.

97. Id. at $1161-62$.

98. Id. at 1161 .

99. E.g., Sabine Sultan Danino, La présomption d'innocence vue de New York en mai 2011. ce qu'en dit la Loi Française, LEGAVoX (May 18, 2011, 3:02 PM) (Fr.), http://www.legavox.fr/blog/maitre-sabine-sultan-danino/presomption-innocence-york-2011- 
But the difference goes beyond our different understandings of privacy. The presumption of innocence simply plays a far less central role in the "generally accepted ideology" of the continental world-inevitably so, because the background institutional assumptions in continental criminal justice are different from ours. Continental law does not start from the assumption that investigators are likely to be either malevolent or incompetent. As specialists in comparative law frequently observe, the continental tradition displays considerable faith in the highly trained, nonadversarial, and bureaucratically supervised officials who conduct its criminal investigations. ${ }^{101}$ Nor does continental law worry overmuch about prejudice among its jurors and lay assessors. They too are professionally supervised. The Continent has mixed courts: Continental jurors and lay assessors deliberate in the presence of, and under the guidance of, professional judges, who can be expected to steer them away from inappropriate avenues of decision making. ${ }^{102}$ The distrust of government that seems to Americans so necessary for safeguarding liberty is simply much less present in continental culture; consequently the American-style presumption of innocence, founded in a reflexive distrust of officialdom, is much less at home.

Yet if continental justice does not share our "generally accepted ideology of a presumption of innocence," it nevertheless leaves far more room than our system does for a presumption of mercy.

\section{Trials of Innocence or Trials of Mercy?}

With the phrase "presumption of mercy" I mean to capture an attitude that shapes the entirety of the criminal justice process and not just the law of sentencing. Sentencing is of course one area where the impact of the presumption of mercy is bound to be felt. A system strongly oriented toward the presumption of mercy will naturally have law presumptively limiting the severity of sentences; and the continental traditions do indeed

francaise-5589.htm [http://perma.cc/B5KT-7UFN]; Die Maxime schrumpft, SÜDDEUTSCHE ZEITUNG (May 20, 2011, 2:44 PM) (Ger.), http://www.sueddeutsche.de/kultur/strauss-kahn-und -die-unschuldsvermutung-kampfbetonte-voreingenommenheit-1.1099639-3 [http://perma.cc/JF33MV4R].

100. E.g., Est-on présumé coupable aux Etats-Unis?, SLATE.FR (May 17, 2011, 11:00 PM) (Fr.), http://www.slate.fr/story/38303/affaire-dsk-questions [http://perma.cc/52RY-TGGZ].

101. See, e.g., Erik Luna \& Marianne Wade, Prosecutors as Judges, 67 WASH. \& LEE L. REV. $1413,1468-69$ (2010). For a powerful general account of the comparative strength of bureaucratic traditions in continental Europe, see John C. Reitz, Political Economy as a Major Architectural Principle of Public Law, 75 TUL. L. REV. 1121, 1127-31 (2001). For a cautious statement of faith in the classically bureaucratically trained German judiciary, see Tatjana Hömle, Moderate and Non-Arbitrary Sentencing Without Guidelines: The German Experience, 76 LAW \& CONTEMP. PROBS., no. 1, 2013, at 189, 207-09.

102. Thaman, supra note 12 , at $245-46$. 
have such law. ${ }^{103}$ But they also display a different conception of the structure and purpose of the criminal trial and a different approach to the problems of exculpation and mercy. I would like to begin with those differences before passing to the law of sentencing.

I start with the structure and purpose of the criminal trial. Consider the contrast between a system of criminal procedure oriented toward the American-style presumption of innocence and a system oriented toward the presumption of mercy. If we share the "generally accepted [American] ideology of a presumption of innocence," and worry primarily about the "nightmare" of the state prosecution of the innocent, our criminal procedure will naturally lay the accent where the American system does: on making a factual determination of whether the defendant belongs to the class of the innocent, who must be protected, or the class of the guilty, who are to be condemned. It will focus on what Akhil Amar calls, in a typically American formulation, "the basic trial value of truth seeking-sorting the innocent from the guilty."104 A criminal court oriented toward the presumption of innocence, like the Court of the Last Judgment in a Romanesque tympanum, will indeed "sort": It will be called upon to determine whether the individuals before it are to be classed among the saved, shepherded toward the sheltering right hand of Christ, or among the damned, driven into the maw of Satan. ${ }^{105}$

The emphasis on this factual "sorting" function has notable implications both for the structure of the trial and for the nature of pretrial disposition. When it comes to the structure of the trial, it makes good sense that a system oriented toward sorting should separate guilt from sentencing. It makes sense in particular that it should put the doctrinal and structural focus on the guilt phase, the phase devoted to the critical sorting that is the primary purpose of the trial. After all, it is during the guilt phase that the critical presumption comes into play ${ }^{106}$ - the presumption of innocence that forces the court to work hard to justify a conviction. Perhaps it also makes sense that a system oriented toward the presumption of innocence should have something like our law of evidence, designed to guarantee that its jurors/fact finders are not prejudiced or even distracted by evidence that is

103. See infra Part VIII.

104. Akhil Reed Amar, Fourth Amendment First Principles, 107 HARV. L. REV. 757, 759 (1994).

105. For the importance of the Last Judgment in Romanesque tympana, see MEYER SCHAPIRO, The Programs of Imagery (i): Themes of Action and Themes of State, in ROMANESQUE ARCHITECTURAL SCULPTURE 97, 113-14 (Linda Seidel ed., 2006).

106. See PARK ET AL., supra note $23, \S \S 4.01-.06$, at $82-88$ (describing the burdens of production and persuasion that a prosecutor must meet and the difficulties involved in doing so). 
not strictly necessary to their narrow sorting task. ${ }^{107}$ Not least, it may make sense that such a system should opt for the American "obstacle course" model of limiting state power, protecting the innocent by making proof during the guilt phase difficult. ${ }^{108}$

As for pretrial disposition, it makes sense that such a system should display one of the most striking, and troubling, features of contemporary American criminal justice: a heavy reliance on plea bargaining. After all, if the purpose of the criminal trial is simply to "sort the innocent from the guilty," there is little point in going to the trouble of holding a trial if the defendant is obviously guilty. A defendant who has no plausible claim of innocence, nor any promising basis for throwing up evidentiary "obstacles" against conviction, arguably has no business putting the state to the expense of trying him. Indeed, we might believe that a manifestly guilty defendant who insists on putting the state to the expense of a trial deserves to pay the "trial penalty" that American criminal judges notoriously impose-the harsh sentence, usually the maximum, visited on obviously guilty defendants who refuse to submit to a plea bargain. ${ }^{109}$

The trial penalty certainly exists in American justice, as criminal judges sometimes quietly admit. You take some of my time; I take some of yours, they proverbially say to defendants. ${ }^{110}$ In a sense it is understandable that such a trial penalty should exist: overburdened American judges cannot hope to limit their caseloads unless they inflict some cost on defendants, who have the power to initiate trials, and the principal cost judges are empowered to inflict is the cost of stiffer criminal penalties.

Nevertheless, understandable or not, the trial penalty is a premier example of how an American system strongly oriented toward the presumption of innocence finds itself depriving the guilty of rights in a way that can shock observers from the Continent. How can a country that makes so much noise about "due process" penalize people because they have the temerity to insist on their due process right to a trial? The answer is that our understanding of the purpose of the trial leaves us few grounds for objecting when judges impose the trial penalty: trial, to us, with its sorting function, is an institution dedicated to identifying people who are in

107. See id. $\$ 5.04$, at $128-130$ (outlining some of the potential purposes served by the general "character ban" in United States courts, including the possibility that juries might be distracted by such evidence which unfairly prejudices the defendant).

108. E.g., id. $\S \S 4.01-.06$, at $82-88$ (describing a few of the obstacles set up to make the prosecution's ability to prove the defendant's guilt more difficult).

109. See, e.g., Candace McCoy, Plea Bargaining as Coercion: The Trial Penalty and Plea Bargaining Reform, 50 CRIM. L.Q. 67, 91 (2005) (describing the disparity in sentencing between cases taken to trial and those resolved through guilty plea).

110. See generally Thomas M. Uhlman \& N. Darlene Walker, "He Takes Some of My Time; I Take Some of His": An Analysis of Judicial Sentencing Patterns in Jury Cases, 14 LAW \& Soc'Y REV. 323 (1980) (finding that judges impose tougher penalties for jury defendants compared with bench and plea defendants). 
fact innocent. Its sole purpose is to make sure that those who are to be saved are extracted from the mass of those who are to be damned. In this as in so many other ways, American rights are rights for the innocent-or at least the colorably innocent-not for the guilty.

Now consider a system of criminal procedure oriented toward the presumption of mercy. Such a system will take quite a different shape, both when it comes to the structure of trial and when it comes to pretrial disposition. "Sorting the innocent from the guilty" cannot be the only purpose, or even the primary purpose, of trial in a system of criminal procedure founded on the presumption of mercy. On the contrary, establishing that the defendant is in fact guilty can only be the first step in a longer process that turns on a very different legal question: how to punish the concededly guilty defendant in ways that are necessary and appropriate, but that do not violate the dictates of conscience, and that are (in the language of contemporary European law) consonant with the demands of human dignity. To put it a bit differently, the purpose of the trial cannot simply be "truth-seeking," as so many comparative law accounts of inquisitorial justice assert. It must instead also be about sentence weighing, a different (and complex) exercise in legal reflection.

The continental trial procedure that shocks us so much is procedure that reflects the imperatives of the presumption of mercy. A continental criminal trial certainly does not neglect the task of "sorting the innocent from the guilty": the court is obliged to make a careful, factual determination that the defendant is guilty of the offense charged. Indeed, as a technical matter the court must make its determination of guilt before it moves on to deliberation about the sentence. ${ }^{111}$ But a continental court does its fact-finding in a different spirit from the way fact-finding is done in an American court, and because the trial has purposes that go beyond mere factual "sorting," the court has reasons to focus on character evidence from an early point in the trial onward.

The basic difference between the adversarial and inquisitorial attitudes toward fact-finding was memorably analyzed thirty years ago by Damaška. ${ }^{12}$ An American criminal trial does its "sorting" by staging a kind of artificial whodunnit during the guilt phase: It asks lay jurors who have never been exposed to the evidence in the case to arrive at a fresh determination of whether the defendant is in fact innocent or guilty of the

111. Code de PROCÉdure PÉNALe [C. PR. PÉn.] [CRIMINAl Procedure Code] art. 362 (Fr.), translation at https://www.legifrance.gouv.fr/content/download/1958/13719/version/3/file/ Code_34.pdf [https://perma.cc/5C98-TLNX]; DIE STRAFPROZESSORDNUNG UND DAS GERICHTSVERFASSUNGSGESETZ: $\S \S 216-95, \S 263$, at 30 (Walter Gollwitzer ed., 25th ed. 2001) (Ger.).

112. See Mirjan R. DamašKa, The Faces of Justice and State Authortty 119-25, 160-64 (1986) (analyzing and comparing adversarial and inquisitorial fact-finding processes). 
offense charged. ${ }^{113}$ By contrast, as Damaška observed, the continental trial is not designed to make a fresh factual determination in quite the same way. It does not stage a dramatic whodunnit. Instead it serves a bureaucratic audit function ${ }^{14}$ : the continental trial is simply one stage in a long, routinized, bureaucratic process during which the work done in the case is repeatedly checked by hierarchical superiors-it is simply one of a series of decidedly undramatic supervisory sessions in which the dossier assembled by professional investigators is vetted to make sure there are no errors. ${ }^{115}$ These continental "audits" happen repeatedly before the trial ever commences. In France, for example, the dossier must be formally audited by a panel of judges before the case is committed to trial. ${ }^{116}$ After the trial, there is provision for de novo appellate auditing everywhere on the Continent as well. ${ }^{117}$

As for the factual audit that takes place at the trial itself: it is certainly not an unimportant event. Errors are sometimes found; it is in the nature of the continental presumption of innocence that the trial audit is taken seriously. Moreover, the panel of auditors at trial includes lay participants, which is something of considerable value for legitimating convictions. Still, though the trial audit is important, the working assumption at trial, as Damaška (himself a former continental criminal judge) argued, is that the dossier has been put together professionally and repeatedly checked beforehand. ${ }^{118}$ Accordingly, even though the court is technically forbidden

113. Id at 38-46.

114. Id. at $192-93$.

115. The errors reviewed in the "audit" may be errors of fact, of course. But it is important to note that they may also be errors of law. In particular, it is important to note that the determination of guilt, in the continental tradition, is a legal determination and not a factual one. That matters a great deal because it means that continental defendants cannot plead guilty. After all, as laypeople, they may simply be wrong about whether they are guilty or not. (This is by no means a purely theoretical possibility: the Wall Street Journal recently ran a telling report about a defendant who almost pled guilty and served time for an act that was later determined at trial not to be criminal at all. Gary Fields \& John R. Emshwiller, Federal Guilty Pleas Soar as Bargains Trump Trials, WALL STREET J. (Sept. 23, 2012, 10:30 PM), http://online.wsj.com/news/articles/ SB10000872396390443589304577637610097206808 [http://perma.cc/AR79-V4DS].) The American common law conception of "pleading guilty" is an inheritance from the Middle Ages: it dates back to a time, centuries ago, when offenses were defined so simply that laypeople could tell whether or not they had committed them. But offenses are no longer so simple, and it is not clear that guilt can easily be ascertained in a hurried plea bargain. Figuring out whether the defendant is guilty may require long and multistage reflection by multiple legal officials. That is a part of what the continental process is intended to achieve. When the continental dossier is "audited," it is checked both to make sure that it rests on a convincing reading of the evidence, and that responsible legal officials have correctly determined that there is good legal reason to deem the accused "guilty" on the basis of what he has done. Permitting pleas of guilty opens the door, not only to unjustified sentences but also to unjustified convictions.

116. C. PR. PÉN., supra note 111, art. 212.

117. See Damaška, supra note 63, at 489-91 (describing the comprehensive system of appellate review on the Continent).

118. Mirjan R. DamašKa, The Faces of Justice and State Authority 206 (1986). 
to consider the sentence until it has made a formal determination of guilt, it is inevitably the case that the court starts weighing what sentence to hand down from the beginning. ${ }^{119}$ Unsurprisingly so. After all, the really fresh question at trial is not whether the defendant is guilty or innocent. The really fresh question is what is to be done with him.

Hence this form of trial focuses a great deal, from its opening moments, on what American law calls "sentencing factors." The large new question to be resolved at trial is not how to sort the innocent from the guilty, but how to punish the guilty without "repressive excess." 220 The answer to that question will necessarily turn on the individualization of punishment: It will revolve around evidence of how dangerous the defendant is, or conversely how much his "course of life" shows him to be a person deserving mercy or offering hope of rehabilitation. It is beneficial to emphasize that the process of reflection on punishment will not necessarily yield a light sentence: the judgment the court makes of the individual may well be tough and the sentence long. What matters is that continental procedure is designed to force careful consideration of whether and how to punish.

The result is a form of trial that comes as a serious shock to American spectators, as reactions to the Knox case show. ${ }^{121}$ But it is essential to recognize that continental trials are not unfair-or at least, not systematically unfair. In fact, the continental form of trial is arguably fairer than the form we cherish in America. Fairer?! The suggestion that continental trial, with its casual exploration of seemingly prejudicial evidence, might actually be fairer than American trial may sound outlandish, but consider carefully the contrast between the continental and American approaches. In theory, American criminal trial requires the strict exclusion of prejudicial evidence from the guilt phase. That is the bedrock principle we swear by. In practice, however, the American law of evidence tolerates many subterfuges by which the prosecution can expose the jurors to damning evidence, and the truth is that jurors learn prejudicial facts about

119. It is of course difficult to persuade continental officers to admit on the record that they begin considering sentencing before the formal decision to convict has been made in conference. Nevertheless, in sufficiently convivial settings I have known them to admit it.

120. Cf. CONSEIL CONSTITUTIONNEL, supra note 9, at 2 (calling for constitutional oversight of the penal system, in order to balance the competing interests, avoid "repressive excess" and limit arbitrariness).

121. See, e.g., Mirabella, supra note 33, at 231 (stating that Americans were outraged that the Italian criminal system appeared to find people guilty before they were tried); Tom Leonard, Only Doubt over Amanda Knox Conviction Is Exactly How They Got It Wrong, TELEGRAPH (Dec. 8, 2009, 7:01 PM), http://www.telegraph.co.uk/news/worldnews/northamerica/usa/6763445/Only -doubt-over-Amanda-Knox-conviction-is-exactly-how-they-got-it-wrong.html [https://perma.cc/ KT9Y-NN7F] (discussing the general view in the American media that the Italian legal system is flawed based on the Amanda Knox trial). 
the defendant all the time. ${ }^{122}$ By contrast, there is little means by which the defense in the American common law can offer favorable character evidence. If the defense puts the character of the defendant in issue, it opens itself up to a proverbial "barrage" of damaging revelations. ${ }^{123}$ (For other reasons too, the tendency in an American trial is to air only unfavorable character evidence.) ${ }^{124}$ The most accurate way to describe the American guilt phase is not to say that it always excludes character evidence, but rather that in practice it tends to consider only character evidence that is unfavorable to the defendant.

Continental trial, so seemingly shocking, is different, because in its consideration of the defendant's character it always gives a hearing to both sides of the story. ${ }^{125}$ The point of the continental courtroom examination of the defendant's "course of life" is not just to determine whether the defendant is dangerous or disreputable - though it most definitely does consider those issues. It is not just to dwell on what we Americans regard as "prejudicial" material. Nor does continental law license the court to fish around in the defendant's life to consider any and all bad acts the defendant may have committed in his life. The purpose of continental law is to arrive at a rounded judgment of how much it is right to condemn the offender for the act charged, given all the circumstances of his biography and life predicament. ${ }^{26}$ Its purpose is to address the fundamental questions that must be addressed under the presumption of mercy: Is it appropriate to punish this person, guilty though he is? Are there factors that argue for

122. E.g., Richard C. Wydick, Character Evidence: A Guided Tour of the Grotesque Structure, 21 U.C. DAVIS L. REV. 123, 132-33 (1987).

123. FED. R. EVID. 404(a)(2)(A) ("[D]efendant may offer evidence of the defendant's pertinent trait, and if the evidence is admitted, the prosecutor may offer evidence to rebut it ....").

124. As I have argued elsewhere, judges have peculiar incentives to permit the admission of unfavorable evidence, since they know that dangerous offenders whose guilt for the particular offense charged cannot be proved may be acquitted unless the jury is permitted to see the larger picture. Moreover, there is one fact about the defendant that cannot be disguised even if he does not take the stand: his race. James Q. Whitman, The Case for Penal Modernism: Beyond Utility and Desert, 1 CRITICAL ANALYSIS L. 143, 176-77 (2014).

125. STGB, supra note $46, \S 46$ (Ger.) (requiring consideration of circumstances that weigh for and against the offender- "Umstände, die für und gegen den Täter sprechen").

126. See Gerhard SCHÄFER ET AL., PRAXIS DER STRAFZUMESSUNG 163-64 (5th ed., 2012) (explaining that German law insists with particular clarity that sentencing factors should play a role only to the extent they bear on the blameworthiness of the defendant for the act committed); Hörnle, supra note 101, at 195 (discussing the German notion that criminal punishment must be proportionate to the seriousness of the crime). After conviction there is also systematic consideration of the character and social circumstances of the offender. See Strafvollzugsgesetz [StVollzG] [Penitentiary Systems Act], Mar. 16, 1976, BundesGeSETzBLATt, Teil I [BGBL I] BGBl I at 518, as amended, $\& 6$ (Ger.), translation at https://www.gesetze-im -internet.de/englisch_stvollzg/englisch_stvollzg.html [https://perma.cc/JG8S-HKDX]; KOMMENTAR ZUM STRAFVOLlZUGSGESETZ 61-64 (Johannes Feest ed., 4th ed. 2000) (Ger.). 
mitigation? Bearing in mind the immense moral gravity of the decision to impose criminal punishment, do we feel that conscience dictates that in this case we ought to spare the rod?

Amanda Knox, for example, benefited from the consideration of such factors, which is mandated under Italian law. It is well worth quoting the trial court's review of the extenuating aspects of the "course of life" of Knox and her codefendant and boyfriend, Raffaele Sollecito, as an illustration of the continental use of the evidence developed at trial. "Apart from the personal use of drugs," the court found:

[T] here is no other evidence of inappropriate behavior that harmed others. No witness has reported violent actions, or even aggression or intimidation by the current defendants against anyone. Rather, there are proven circumstances in which one and the other, [both defendants] not only worked diligently and profitably at their studies, as their status as students required them to do (Raffaele Sollecito was on the eve of graduation and Amanda Knox successfully and consistently dedicated herself to her lessons that she attended at the University) but they were also available [to help] others (Raffaele Sollecito was supposed to accompany Jovana Popovic to the train station on the night of November 1st) and undertook the tasks of gainful employment (Amanda Knox had gone to work nights at Diya Lumumba's bar) that added to the demands of their studies and attendance of their lessons. By law these are significant factors [requiring mitigation of their punishment for the offense for which they have been convicted].

Both defendants are extremely young, and were still young at the time of the commission of the offense. The inexperience and immaturity natural to youth was accentuated by the context in which they found themselves, different from the context in which they had grown up and deprived of customary points of reference (family, friends, long-time acquaintances, their native region and city of origin) that could have provided helpful support, feedback, and ongoing guidance in the decisions of everyday life. Thus Amanda Knox, who came to Perugia not even two months earlier, motivated only (based on the acts considered) by curiosity and the desire for new experiences, found herself in a private life without the protection and sanctuary offered by her family (this consideration appears all the more significant because of how much Amanda said about the intense and continuous relationships that existed in her 
'great' family); similarly Raffaele Sollecito, whose father called continuously, a sign that the son still needed someone constantly to listen and provide support and guidance; calls, however, that were inadequate to provide the closeness and control evidently still needed. ${ }^{127}$

On the basis of these findings, the court was legally obligated to mitigate Knox's sentence. It is worth emphasizing how striking that fact is. These findings, which paint such a touching picture of Knox as an innocent abroad, were made by a trial court that, in the rest of its judgment, clearly regarded her as mendacious and vicious (not to mention lubricious). ${ }^{128}$ Yet Italian law required this court to weigh the interests of mercy-and it did so, as continental courts all do. The fact that continental courts treat such "course of life" matters as centrally important from the opening minutes of the trial may dismay Americans, but considering course of life is not meant to facilitate the conviction of the innocent by any means; it can work to the benefit of the guilty, and it contributes materially to the absence in the continental world of American-style harsh justice.

As for continental pretrial disposition, it too takes different forms from those we find in America. Because the core purpose of the continental trial is not simply to invite lay jurors to "sort the innocent from the guilty," there is not the same systemic pressure to avoid trial for those whose guilt is

127. Sentenza della Corte d'Ass., 4 marzo 2010, n. 7/2009, at 421-22 (It.), http://perugiamurderfile.org/download/file.php?id=3379 [https://perma.cc/QB7F-SCGV] (“Al di là dell'uso personale di droga, non sono risultati comportamenti disdicevoli dagli stessi posti in essere in danno di altri. Nessun teste ha riferito di azioni violente, ovvero di aggressioniintimidazioni realizzate dagli attuali imputati a danno di chicchessia. Sono anzi risultate circostanze per le quali sia l'uno che l'altra, oltre ad impegnarsi con diligenza e profitto nello studio al quale come studenti erano tenuti (Raffaele Sollecito era alla vigilia della laurea e Amanda Knox si impegnava con profitto e continuità nelle lezioni che frequentava all'Università) si manifestavano disponibili con gli altri (Raffaele Sollecito per la sera del 1 novembre avrebbe dovuto accompagnare Jovana Popovic alla stazione) e accettavano la fatica di un'attività lavorativa (Amanda Knox andava a lavorare la sera al pub di Diya Lumumba) che si aggiungeva a quella richiesta dallo studio e dalla frequenza delle lezioni. Circostanze queste che appaiono significative ex art. 133 co. 2 n.2 c.p. Entrambi gl'imputati sono giovanissimi e lo erano ancora di più all'epoca dei fatti. L'inesperienza e l'immaturità proprie dell'età giovanile erano accentuate dal contesto in cui entrambi si trovavano perchè diverso da quello nel quale erano cresciuti e privo dei punti di riferimento abituali (la famiglia, gli amici, le conoscenze coltivate negli anni, il proprio paese e città di origine) che potevano valere a costituire sostegno, confronto e verifica continui nelle determinazioni della vita quotidiana. Cosi Amanda Knox, arrivata a Perugia da neanche due mesi, animata soltanto (per quanto gli atti hanno consentito di valutare) da curiosità $\mathrm{e}$ dal desiderio di fare le più diverse esperienze, si trovava a vivere privata di quella protezione e riparo costituiti, in particolare, dalla sua famiglia (al riguardo appare quanto mai significativo quanto dichiarato da Amanda in ordine alla sua 'grande' famiglia, ai rapporti intensi e continui all'interno esistenti); analogamente Raffaele Sollecito al quale il padre telefonava di continuo, quale segno della necessità che il figlio ancora aveva di una presenza che continuamente l'avesse ascoltato, sostenuto e indirizzato; telefonate però inidonee a costituire quella vicinanza e controllo evidentemente ancora necessari (circostanze significative ex art. 133 co. 2 n. 4 cp).").

128. See infra Appendix. 
obvious. The inquisitorial trial serves purposes that cannot be replicated through a plea bargain. It serves, first of all, to audit once again the work that has been done by professional investigators and magistrates. But it also serves to ponder the weighty and morally challenging question of how to punish the defendant. Not least, it serves a function important for offender and society alike: to bring suitable ritual solemnity and gravitas to the solemn and grave business of imposing criminal punishment. ${ }^{129}$ Indeed, in the terminology of the Italian criminal justice system that convicted Knox, a trial is a rito, a ritual. ${ }^{130}$ In a world in which those functions seem essential, it seems necessary to hold a trial regardless of whether the defendant is (as most defendants are) obviously guilty.

That does not mean that the continental world never engages in pretrial or summary disposition. Caseloads are burdensome in the continental world just as they are in the United States, and there is corresponding pressure to avoid full-scale trial if possible. Continental law includes a variety of avenues for pretrial disposition and summary trial disposition, some of which even go by the American name "plea bargaining." "131 But in line with the presumption of mercy, there is a strong tradition in continental law of condemning the use of such alternative avenues in cases involving the sort of heavy punishment that follows conviction for a major offense. If a heavy punishment is to be imposed, continental tradition generally holds, there must be a full-dress trial precisely because imposing heavy punishment is such a heavy matter. ${ }^{132}$ There are no life sentences as a result of continental plea bargains or summary trials. There are only mitigated, often sharply mitigated, sentences-typically half or sometimes two-thirds of the nominal sentence for the crime charged. ${ }^{133}$ (Such a lighter sentence

129. For a classic French reflection on the ritual function of trial, see ANTOINE GARAPON, BIEN JUGER: ESSAI SUR LE RITUEL JUDICIAIRE 1, 14, 20 (1997) (Fr.).

130. See infra Appendix.

131. Maximo Langer, From Legal Transplants to Legal Translations: The Globalization of Plea Bargaining and the Americanization Thesis in Criminal Procedure, 45 HARV. INT'L L.J., 1, 3 (2004).

132. For the Italian experience, see the Appendix, infra. For the German tendency to use bargaining for "white-collar, traffic and drug offenses," see JULIA PETERS, URTEILSABSPRACHEN IM STRAFPROZESS: DIE DEUTSCHE REGELUNG IM VERGLEICH MIT ENTWICKLUNGEN IN ENGLAND \& WALES, FRANKREICH UND POLEN 10 (2011). As this suggests, the practice reflects a larger tendency to treat nonviolent offenses as relatively less severe. The counterpressures are, however, certainly strong, and in a personal communication Professor Hörnle suggests to me that under the 2009 German statutory provision permitting sentence bargaining, STRAFPROZESSORDNUNG [STPO] [CODE OF CRIMINAL PROCEDURE] § 257c (Ger.), translated at https://www.gesetze-im -internet.de/englisch_stpo/englisch_stpo.html [https://perma.cc/59TS-H5WN], she thinks it is "probable" that major sentences are also handed out and that the sense of the need for a formal ritual is declining in Germany. She adds, however, that it is "hard to say" whether in fact lengthy sentences are given as a result of bargains in Germany.

133. Here it is important to emphasize that continental plea bargaining involves only sentence bargaining, not charge bargaining. The only possible result of a continental bargain is a downward departure from the notional sentence for the "correct" charge; prosecutors are not 
was given to Rudi Guede, the third defendant in the Knox case. $)^{134}$ It is a sad thing that continental justice must resort to these expedients, and a sad thing that modern societies in general are unable to provide full-dress justice for all. Still, it is essential to recognize that continental law pursues its expedients in ways intended to respect the spirit of the presumption of mercy. If the full formal ritual of a trial cannot be held, in the continental view, punishment must be lightened.

The continental form of trial that has grown out of all this is deeply unsettling to Americans. The continental defendant standing in the dock, interrogated about his "course of life" under the gaze of the jurors, looks to us like an individual already condemned in a shadowy bureaucratic process, with no opportunity to rebel. To our eyes, a continental trial seems to rest on the de facto presumption of guilt characteristic of Packer's "assembly line" model of criminal justice as crime control: "Once a man has been [arrested and] investigated ... then all subsequent activity directed toward him is based on the view that he is probably guilty."135 Focusing so heavily, not on due process; not on whether there has been investigative misconduct; not on "sorting the innocent from the guilty"; not on organizing the justice system around suspicion of state power; but instead on how to punish the defendant appropriately, seems to us to turn justice on its head. It is impossible for Americans not to think of Lewis Carroll's Queen of Hearts, crying "Sentence first-verdict afterwards," and impossible for them not to remember the rest of the passage that follows:

"Stuff and nonsense!" said Alice loudly. "The idea of having the sentence first!"

"Hold your tongue!" said the Queen, turning purple.

"I won't!" said Alice.

"Off with her head!" the Queen shouted at the top of her voice. ${ }^{136}$

American believers in the innocence of Amanda Knox were convinced that they were witnessing just such a looking-glass exercise of inquisitorial justice, visited on a confused girl trapped in an alien continental justice system. ${ }^{137}$

permitted to threaten a wide range of possible charges. As a result, the "game" of continental bargaining is quite different, as is the role played by the prosecutor, who is empowered only to offer mercy for cooperation, not to brandish an arsenal of threats. It is also of fundamental importance that continental practice contemplates active involvement on the part of the judge. This Article is not the place to review the contrast in plea bargaining practice in full, however.

134. See infra Appendix.

135. Packer, supra note 1 , at 11 .

136. LeWIS CARroll, ALICE'S ADVENTURES IN WONDERLAND 158 (1865) (emphasis added).

137. For a typical account invoking Alice in Wonderland, see MARK C. WATERBURY, THE MONSTER OF PERUGIA: THE FRAMING OF AMANDA KNOX 134-35 (2011). 
And-regardless of whether Knox was in fact innocent or guiltythere is no doubt that the continental mode of justice carries dangers and defects. Continental investigators do not always have sufficient resources to pursue their work in full obedience to the ideals of the law; Italian policing in particular is troubled by budget shortfalls and turf battles. ${ }^{138}$ The criminal defamation case brought against Knox's parents was shocking, in my view; it was the product of a continental tradition that promotes too much respect for professional investigators and that permits too many means of enforcing that respect through law. ${ }^{139}$ The Sarkozy wiretaps went too far too, as many in France itself agree. ${ }^{140}$ The trial court's focus on Knox's "course of life" arguably went too far as well: her initial conviction depended on a troubling mix of circumstantial evidence and lurid speculation about her sexual proclivities. ${ }^{141}$ No doubt there are other cases in which courtroom exposure of the defendant's character yields injustice. Continental justice is also undoubtedly prey to a disturbing tendency found to some extent in all systems: the tendency to convict offenders who seem guilty of something, even if they are not clearly guilty of the specific offense with which they have been charged. ${ }^{142}$ Not least, as Americans are likely to argue, the application of mercy inevitably runs the risk of invidious discrimination: after all, Amanda Knox received mercy because she was a diligent university student with a supportive family. Isn't it obvious that that sort of mercy is mercy for well-to-do people, not for the poor and socially disadvantaged? European-style sentencing requires discretion, and Americans are sensitive to the truth that discretion can easily degenerate into discrimination. ${ }^{143}$

138. Barbie latza Nadeau, ANgel Face: Sex, Murder, and the Inside Story of AMANDA KNOX 51-53, 68-72 (2010).

139. Thus French law, for example, criminalizes disrespectful conduct with regard to government officials. This offense is denominated "contempt." C. PÉN, supra note 51, art. 433-5.

140. Marc Leplongeon, Ecoutes de Nicolas Sarkozy: faut-il renforcer le secret professionnel?, LE POINT (Oct. 2, 2014, 7:25 AM), http://www.lepoint.fr/justice/ecoutes-de-nicolas-sarkozy-faut -il-renforcer-le-secret-professionnel-02-10-2014-1868564_2386.php [http://perma.cc/US3J -ZSQE].

141. See infra Appendix.

142. See Mirjan R. Damaška, Propensity Evidence in Continental Legal Systems, 70 CHI.KENT L. REV. 55, 66 (1994) (noting how the easy access of continental adjudicators to prior acts evidence that would not be admitted in a common law jurisdiction may tip the scales of justice against the accused).

143. Classically KenNeTH CUlP Davis, POLICE DisCRETION 143-44 (1975), who notes that the rationale for limiting discretion is not that human beings cannot exercise wide discretion justly and beneficially, but rather that, no matter the screening, a large portion may be expected to abuse their power and some of those officers will engage in serious abuses of power. $C f$. Hörnle, supra note 101, at 201 (explaining how court's regional cultures and other factual non-normative influences affect sentencing decisions in Germany). 
Thoughtful Europeans too can see the dangers and defects, at least some of the time. They know that their investigators sometimes slip into authentically abusive practices: Germans have expressed outrage and anxiety over their police Trojan horse program, for example; ${ }^{144}$ and the French have been struggling to impose limits on the investigative process. ${ }^{145}$ The Italians, for their part, have made a sustained effort to borrow from adversarial procedure. ${ }^{146}$ Europeans do sometimes worry that defendants may suffer prejudice as a result of the wide range of evidence presented against them. In 1993, for example, French reformers made a serious, though unsuccessful, effort to introduce American-style evidentiary exclusions at trial, precisely because they believed that the danger of prejudice was intolerably great. ${ }^{147}$ The Germans too have a history of attempts-very halfhearted ones, from the American point of view-to exclude "course of life" evidence that might create prejudice. ${ }^{148}$

But it is never right to judge alien systems solely on their excesses and defects. The right question is not whether systems with a strong orientation toward mercy make mistakes; of course they do. The question is whether on balance an orientation toward mercy makes for a more humane criminal justice system. (And in any case it is always important to remember that continental sentencing is far milder than American. Injustices are done in both worlds, but when they are done in America the convicted victims pay a much steeper price than the victims in Europe.) As long as we keep our critical faculties alert, we have something to gain by stifling our suspicions and making the effort to appreciate inquisitorial values on their own terms.

\section{Mercy or Exculpation?: The Nineteenth-Century Divergence}

So far I have been discussing our clashing understandings of the structure and function of the criminal trial and pretrial disposition, but the divergence does not end there. Our transatlantic differences also have to do with complexities in our divergent histories of mercy and exculpation, which have resulted in fundamental clashes over the proper place of jury trial and criminal law doctrine.

144. E.g., David Gordon Smith \& Kristen Allen, The World from Berlin: Electronic Surveillance Scandal Hits Germany, SPIEGEL ONLINE INT'L (Oct. 10, 2011, 2:11 PM), http://www.spiegel.de/international/germany/the-world-from-berlin-electronic-surveillance -scandal-hits-germany-a-790944.html [http://perma.cc/SU42-YKW8].

145. E.g., JACQUELINE HOdGSON, FRENCH CRIMINAL JUSTICE: A COMPARATIVE ACCOUNT OF THE INVESTIGATION AND PROSECUTION OF CRIME IN FRANCE 27-29 (2005) (describing ongoing reforms to French criminal procedure).

146. See infra Appendix.

147. See Gaston Stefani, Georges Levasseur \& Bernard Bouloc, Procédure PÉNALE $\S 2$, at 118-24 (22d ed. 2010) (discussing the limits on admissible evidence).

148. HENRI ANGEVIN, LA PRATIQUE DE LA COUR D'ASSISES 375 (4th ed. 2005); HEGHMANNS \& SCHEFFLER, supra note 31, at 673-78; Granderath, supra note 28, at 320. 
As I suggested earlier, the juristic dichotomy between the presumption of mercy and the presumption of innocence is related to the political dichotomy between more and less statist orientations. The practice of graciously showing mercy to deserving offenders-declaring them "guilty but forgiven"-comes naturally to more statist orders, orders with what Damaška calls a hierarchical structure of authority; while the practice of exculpating them-declaring them "innocent," and therefore immune to the state's punishing power-comes more naturally to political cultures with deeper antistatist tendencies. ${ }^{149}$

We must bear those dichotomies in mind as we try to understand how our Western systems of justice differ. The contrast between American justice and continental justice is the contrast between two different attitudes toward mercy and exculpation. That contrast is not a simple or wholly straightforward one. There are practices of both exculpation and mercy on both sides of the Atlantic. Nevertheless, there are telling differences. The continental traditions, much more respectful of state power and much more deferential to professional expertise, tend to exculpate in a different way from the way Americans do; and in the contemporary world, mercy has a much deeper hold on continental justice than on American justice.

To understand these differences, we must look to history, for they are the products of two significant historical divergences: one in the nineteenth century, one in the twentieth. In the nineteenth century, the common law and continental worlds both rejected the traditions of ancien régime monarchical government, which made heavy use of the pardoning power. Both the inquisitorial and adversarial traditions moved systematically away from mercy, and toward norms of exculpation: it became a commonplace in every part of the nineteenth-century West that deserving offenders should be declared "innocent" rather than "guilty but forgiven." But the common law and the continental traditions adopted different approaches to that shared end: the common law put its trust more in the work of lay jurors, while the continental world put its trust more in the work of professional jurists. This nineteenth-century divergence was followed by a twentiethcentury one: In the twentieth century, the Continent showed much more openness to modernized forms of mercy than America did. To understand the conflicts in our contemporary sensibilities, we must consider each of these historic divergences in turn.

149. See WHITMAN, supra note 45 , at $14,92-93$ (arguing that the relative power-defined as the relative ability to intervene in civil society without losing political legitimacy-and autonomy-defined as a state being steered by bureaucracies that are relatively immune from changes in public opinion-of continental states promotes mercy in continental society and criminal punishment, exemplified by the granting of amnesties); see Damaška, supra note 63, at 483-507 (discussing the centralization of authority and the structure in what the author terms the hierarchal structure of authority); infra notes 169-76 and accompanying text (discussing the antistatist mechanism of exculpation of the power of the jury to acquit). 
I begin with the nineteenth-century divergence. Before the late eighteenth century, secular justice everywhere in the Western world tended to rely on mercy to make distinctions between offenders. Killers and thieves alike were convicted with relative dispatch, in trials that generally dwelt less on refined problems in culpability than modern trials. The real action came after the formal conviction when offenders pled for mercy, usually addressing themselves to the pardoning power of the prince. ${ }^{150}$ Their pleas for mercy often involved their life circumstances and record of good deeds-the sorts of things that are now considered when a continental court investigates the "course of life" of the defendant. But they also sometimes included claims that we would now think of as sounding in justification or claiming involuntariness-claims that in a system oriented toward culpability might have resulted in acquittal. ${ }^{151}$

Inevitably these systems made heavy use of strict and vicarious liability. ${ }^{152}$ Eighteenth-century criminal law throughout the Western world was designed to facilitate rapid and easy conviction. In particular, it was designed to deal with what seemed to many observers the most pressing problem of criminal justice: highway robbery, a group offense. ${ }^{153}$ As a result, eighteenth-century secular criminal law made few fine distinctions in its doctrines of mens rea. ${ }^{154}$ Open-ended doctrines of liability made it easy to capture dangerous offenders who might otherwise go free for want of clear evidence of intent. Doctrines of vicarious liability in particular made it easy to capture group offenders like highway robbers.

150. In France, the technically princely pardoning power had largely been assumed by the cours souveraines. See generally Bernard Schnapper, Les Peines Arbitraires du XIII Au XVIII Siècle (Doctrines Savantes et Usages Francais), 41 TIJDSCHRIFT VOOR RECHTSGESCHIEDENIS 237 (1973) (explaining that offenders could plead for mercy from a lord after being convicted). There is much more to say about the use of premodern grace than I can explore here. See especially Douglas Hay, Property, Authority and the Criminal Law, in AlBION'S FATAl TrEe: CRIME AND SOCIETY IN EIGHTEENTH-CENTURY ENGLAND 17 (Douglas Hay et al. eds., 1975); the critique of John Langbein, Albion's Fatal Flaws, PAST \& PRESENT, Feb. 1983, at 96; and my comments at WHITMAN, supra note 45 , at 260 n.46. For the deeper religious tradition behind this, see generally ROBERT JACOB, LA GRÂCE DES JUGES: L'INSTITUTION JUDICIAIRE ET LE SACRÉ EN OCCIDENT (2014), exploring the impact of religion on the justice system of Medieval Europe; and Thomas J. McSweeney, The King's Courts and the King's Soul: Pardoning as Almsgiving in Medieval England, 40 READING MEDIEVAL STUD. 59 (2014).

151. For the presence of culpability questions in pardoning practice in the English eighteenth century, see BLACKSTONE, supra note 67, at *188; and for the Middle Ages, now the research of Kamali, supra note 67, at 14-24. This question deserves more careful and extensive investigation.

152. BLACKSTONE, supra note 67, at *293-95.

153. See John H. Langbein, Shaping the Eighteenth-Century Criminal Trial: A View from the Ryder Sources, 50 U. CHI. L. REV. 1, 84-85 (1983) (discussing how highway robbery and other gang offenses "most tested the primitive law enforcement capacity of the day").

154. See Frances Bowes Sayre, Mens Rea, 45 HARV. L. REV. 974, 1006 (1932) (observing that criminal culpability in the eighteenth century was based on the defendant's ability to distinguish good from evil). 
The most familiar example of such a pre-nineteenth-century system, to American readers, is the eighteenth-century English common law: despite the availability of jury trial, eighteenth-century English offenders were regularly convicted in rapid trials, but then applied to the king for pardons. Royal pardons were then regularly granted, and the statutory penalty that guilty offenders faced - ordinarily death-was regularly commuted into transportation to the American colonies. ${ }^{155}$ Comparable systems, putting the accent on pardoning, existed everywhere in the Western world. ${ }^{156}$

The latter part of the eighteenth century, however, saw a large-scale reaction against this routine recourse to monarchical mercy, and in that reaction we see the making of the two strains of modern Western criminal law. The reaction, which swept up figures like Beccaria, Kant, and many lesser known writers, was closely associated with the spread of republicanism, and it reflected a spirit of hostility toward monarchical rule. The exercise of the pardoning power was central to the maintenance of monarchical legitimacy, and it belonged to a hierarchical order in which justice descended de haut en bas, in which social superiors graciously condescended to show favor to some of their subjects. Kant gave expression to the distaste that many of his late eighteenth-century contemporaries felt for such forms of discretionary monarchical justice: "The right ${ }^{157}$ of pardoning offenders (ius aggratiandi) whether through mitigating or wholly commuting their punishment, is probably the greasiest of all the rights of the sovereign, used to burnish the glory of his majesty, while doing injustice of a high order."158 It was in the nature of mercy that it was accorded to some but not all, and that it was used to reinforce monarchical legitimacy. This was a form of "injustice," a violation of fundamental norms of equality. The proper alternative, from the point of view of reformers of the period, was a law firmly oriented toward exculpation. Indeed, it was difficult for them to imagine a society that was

155. J. M. BEATTIE, CRIME AND THE COURTS IN ENGLAND: 1660-1800, at 470-519 (1986). For further references, see, for example, ALLYSON N. MAY, THE BAR AND THE OLD BAILEY, $1750-1850$, at 13 (2003).

156. For the central European tradition, and the shift in the nineteenth century, see H. Krause, Gnade, in 1 HANDWÖRTERBUCH ZUR DEUTSCHEN RECHTSGESCHICHTE 1714 (1971).

157. The term Recht here is of course ambiguous, conveying both "law" and "right."

158. IMMANUEL KANT, DIE METAPHYSIK DER SITTEN $§ 49-E(I I)$, at 165 (Karl Vorländer ed., Felix Meiner 1922) (1797) ("Das Begnadigungsrecht... für den Verbrecher, entweder der Milderung oder gänzlichen Erfassung der Strafe, ist wohl unter allen Rechten des Souveräns das schlüpfrigste, um den Glanz seiner Hoheit zu beweisen, und dadurch doch im hohen Grade unrecht zu tun."). For Voltaire's more essayistic, and far less radical, condemnation, see Letter 12402: Voltaire to Jean Baptiste Jacques Élie de Beaumont, 26, Sept. 1765, in 59 VOLTAIRE, CORRESPONDANCE 91 (Theodore Besterman ed., 1960) ("[L]es cas les plus graciables échappent a l'humanité du souverain. [The cases most likely to be pardoned escape the monarch's humanity.]"). For the English parallels, see DAVID J. A. CAIRNS, ADVOCACY AND THE MAKING OF THE ADVERSARIAL CRIMINAL TRIAL 1800-1865, at 56-66 (1998). 
based on true respect for republican egalitarianism unless that society's criminal justice rested on the strict, nondiscretionary application of the law according to well-defined culpability principles. The republican form of government had to favor exculpation over mercy.

Reform agitation grew over the latter decades of the nineteenth century, and it came to a head in the French Revolution and after. There was a slow, seismic shift from mercy to exculpation that affected all of the Western systems by 1870 at the latest; just as there was a kind of "movement," in Henry Maine's famous phrase, "from status to contract" in the mid-nineteenth century, there was a movement from mercy to exculpation. ${ }^{159}$ Call this the culpability revolution of the long nineteenth century, from roughly 1770-1870. The French Code Pénal of 1791 set the tone for the doctrinal reforms that would follow, especially on the Continent. Enacted amid attacks on the royal pardoning power by revolutionaries, ${ }^{160}$ the new Code put a firm emphasis on fixed penalties and considerations of culpability that were designed to guarantee that deserving offenders were acquitted, rather than being convicted and left to throw themselves on the mercy of the King. As the Code repeatedly insisted, in cases of unintentional or justified homicide, "il n'existe point de crime," there simply exists no crime. ${ }^{161}$ Deserving republican offenders were innocents, not guilty candidates for royal forgiveness. ${ }^{162}$ As for undeserving offenders: they were to be punished in the full measure specified by the law, without hope of pardon.

Over the next eighty years, the old traditions of princely mercy went into steady decline throughout the Western world, while the accent shifted increasingly toward exculpation. This is not the place to trace this highly variable and complex process of change, which was connected with the spread of jury trial in Europe, the persistence of royal grace in England, and many other factors, in full. (Much of the complexity of that process is on view in a great transitional case that we all teach, $R v$. Dudley and Stephens, ${ }^{163}$ in which the court discoursed at length on problems in culpability, while the defendants still benefited, as late as 1884 , from a royal pardon. ${ }^{164}$ ) What I would like to emphasize is that the process was

159. Alan Cusack, From Exculpatory to Inculpatory Justice: A History of Due Process in the Adversarial Trial, 2 LAW, CRIME \& HIST., no. 2, 2015, at 1, 20.

160. Among many examples, see Jacques Jallet, Sur la peine de mort, L'ESPRIT DES JOURNAUX, FRANÇOIS ET ÉTRANGERS, March, 1791, at 172 (Fr.).

161. Loi du 25 septembre, 6 octobre 1791 Code Pénal [Penal Code of 1791], 3 Collection COMPLÈTE, DÉCRETS, ORDONNANCES, RÈGLEMENTS ET AVIS DU CONSEIL D'ÉTAT (DUVERGIER \& BOCQUET) [DUV. \& BOC.], 1834, p. 352, pt. II, tit. II, § 1, art. 1, at 361 (Fr.).

162. Yes, I know that France was not a republic in 1791 . Nevertheless, the drive to introduce republican norms into the law was strong.

163. R v. Dudley \& Stephens [1884] 14 QB 273 (Eng.).

164. Id. at $279,281-88$. 
largely complete by around 1870 , and that it took significantly different forms in the common law and continental worlds-the different forms that we now find mutually shocking.

Continental jurists, following the lead established in the late eighteenth century, made a systematic century-long effort to establish rigorous principles of culpability. We see such efforts throughout the Continent. ${ }^{165}$ In particular, we see jurists systematically working to eliminate one aspect of pre-nineteenth-century secular criminal law that seemed to them highly objectionable: the presence of forms of strict and vicarious liability. Offenders were to be convicted strictly for the commission of acts they themselves had provably committed intentionally, or perhaps through narrowly defined forms of culpable negligence. ${ }^{166}$ No forms of strict or vicarious liability could be tolerated in a properly conceived system of criminal justice in an age of limits on state power.

The effect of the culpability revolution on Anglo-American common law was different. The common law is much more substantively conservative than the continental traditions, and it never witnessed any comparably successful systematic effort to eliminate strict and vicarious liability. As one New York lawyer wrote in 1852, explaining a doctrine that would have seemed inexplicable to continental lawyers who were eager to eliminate the irrationalities of the past, "there can be no doubt that whatever was a felony at common law ... is still indictable as such."167 To be sure, there were some serious efforts to work out culpability doctrines in the common law, especially in the latter part of the century. ${ }^{168}$ Nevertheless, the systematic drive that is always present in continental law

165. Among many examples, two more or less at random from the mid-1850s include C.J. AMECKE, DAS PREUBISCHE STRAFRECHT 52 (1853) (Ger.) (describing questions the court should consider about culpability, such as the whether the defendant began the act without responsibility or whether other reasons to exclude certain punishments are present); E. TRÉBUTIEN, COURS ELÉMENTAIRE DE DROIT CRIMINEL 91-92 (1854) (Fr.).

166. See James Fitzjames Stephen's assessment of the differences between nineteenth-century English and continental (here French) homicide law, in 3 JAMES FITZJAMES STEPHEN, A HISTORY OF THE CRIMINAL LAW OF ENGLAND 91-107 (1883). I have traced this process in outline in James Q. Whitman, The Transition to Modernity, in THE OXFORD HANDBOOK OF CRIMINAL LAW 84 (Markus D. Dubber \& Tatjana Hörnle eds., 2014), and argued there that the nineteenth-century analysis of culpability was ultimately borrowed from the Church. Once again, it is important to observe that there are inevitable complexities that cannot be discussed here, notably in the law of complicity.

167. Olvive Lorenzo Barbour, a Treatise on tHE CRIMINAL LAW OF THE STATE of NEW YORK 19 (2d ed. 1852). Barbour continued, describing the critical nature of the nineteenthcentury transition to modernity: "But ... all punishments prescribed by the common law ... are prohibited." Id.

168. Above all, see generally STEPHEN, supra note 57, which continues to set the terms for much of our treatment of the criminal law. Despite the work of Stephen, it has to be said that it can be a struggle to extract criminal law doctrine from most of the nineteenth-century literature, which generally hews closely to statute and precedent and is overwhelmingly oriented toward jury procedures. 
was, as always, less present in the common law world; the vague and casual doctrinal approach to culpability of the eighteenth century persisted, in offenses like conspiracy and felony murder. ${ }^{169}$

Needless to say, though, that does not mean that the nineteenth-century common law world had no commitment to limiting the historic power of monarchical government. It most certainly did. But instead of developing rigorous culpability doctrines, the nineteenth-century common law invested heavily in a mechanism of exculpation with a long antistatist history: the power of the jury to acquit. Especially since the latter part of the seventeenth century, the jury had exercised the power to acquit by giving the general verdict of "not guilty." 170 The nineteenth-century common law made much of that tradition: Every common law jurisdiction in the nineteenth century gloried in jury trial. ${ }^{171}$

But of course the common law habit of glorying in the institution of jury trial has always been accompanied by an undertone of distrust for the persons who actually serve as jurors, and that distrust influenced nineteenth-century developments too. It expressed itself in the rise of the modern form of bifurcation of the criminal trial and the modern law of evidence allied with it.

Before the middle decades of the nineteenth century, there was no practice of limiting the guilt phase to narrow evidentiary questions about the culpability of the defendant for the act charged. On the contrary, well into the early nineteenth century, the conduct of the guilt phase permitted the jurors to hear freewheeling and wide-ranging discussion of the prior history and course of life of the defendant, of the kind that still exists in continental law. Additionally, into the early nineteenth century, defendants commonly faced what Bruce Smith describes as a statutory presumption of guilt; ${ }^{172}$ and what deserving offenders hoped for was primarily the recommendation of a royal pardon. ${ }^{173}$ Only over the period from 1820 to

169. STEPHEN, supra note 166 , at 91 .

170. E.g., Bushell's Case (1670), 124 Eng. Rep. 1006 (standing as a famous example of a seventeenth-century jury returning a not guilty verdict to effect an acquittal).

171. See, e.g., LAWRENCE M. FRIEDMAN, CRIME AND PUNISHMENT IN AMERICAN HISTORY 251 (1993) (observing that in early American history, "the official theory exalted trial by jury," and noting that as America expanded westward, jury trials replaced existing territorial methods for handling crimes); Michael Chesterman, Criminal Trial Juries in Australia: From Penal Colonies to a Federal Democracy, LAW \& CONTEMP. PROBS., Spring 1999, at 69, 71 (noting that the first states of the Commonwealth of Australia all adopted the jury trial).

172. Bruce P. Smith, The Presumption of Guilt and the English Law of Theft, 1750-1850, 23 LAW \& HIST. REV. 133, 135 (2005).

173. See Anat Horovitz, The Emergence of Sentencing Hearings, 9 PUNISHMENT \& SOC'Y 271, 276 (2007) (describing the importance of evidence heard during trial in judicial recommendations for royal pardons). For the character of pre-nineteenth-century trial, see generally the fundamental work of Langbein, supra note 57, his magisterial JOHN H. LANGBEN, THE ORIGINS OF ADVERSARY CRIMINAL TRIAL (2003), and the description in MAY, supra note 155, at 21 . For the critique of Langbein as overstating the extent to which the modern form of 
1870 or so did the modern form of common law bifurcation take hold. During those decades, while continental jurists were engaged in elaborating strictly ordered conceptions of culpability, the common law was elaborating its own strictly ordered law of evidence, designed to limit the focus of the jury trial exclusively to the offense charged. ${ }^{174}$

The result, by 1870 or so, was a profound divergence in Western understandings of the demands of justice. In the common law countries it came to seem self-evident orthodoxy that "prejudicial" evidence should be generally excluded from the guilt phase, in order that the procedural focus on the question of the defendant's culpability should be untainted. Acquittal, however, was to come in the opaque form of the general verdict, with no careful reason-giving by the jury. The Continent, by contrast, insisted on rigorous doctrinal attention to questions of culpability. It is not overly schematic to say that where the common law put its faith in lay jurors, the Continent put its faith in trained jurists.

The common law and the continental traditions were thus both revolutionized over the first two-thirds of the nineteenth century, but in ways that today seem mutually alien and mutually shocking. The two systems seem mutually shocking for a reason that deserves some emphasis. While both the common law and the continental traditions theoretically shifted all the emphasis to questions of culpability in the nineteenth century, in practice both evolved in such a way as to leave room for considerations of defendant dangerousness. The Continent embraced strict forms of substantive culpability, but at the same time it left procedural room for the court to consider damning evidence. Hence the dismay of common law observers of a continental trial, who see a system that is far too procedurally open to the taint of "prejudicial" considerations of the dangerousness of the defendant. But the common law approach that emerged by 1870 is equally dismaying to continentals. For while the common law excludes prejudicial evidence, at least in theory, it leaves doctrinal room, through its seemingly atavistic doctrines of strict and vicarious liability, for the conviction of dangerous offenders who might have escaped liability under the stricter

adversarial trial had already emerged by the end of the eighteenth century, however, see CAIRNS, supra note 158 , at 54 .

174. See, e.g., MAY, supra note 155 , at 109 (noting the development and use of evidentiary rules to focus the scope of jury trials on the offense at hand). For the continuing heavy reliance on character witnesses into the $1830 \mathrm{~s}$, see $i d$. at $108-09$, and for the shift in the later nineteenth century, see Whitman, supra note 124 , at $177 \mathrm{n} .151$. 
continental doctrinal regime. ${ }^{175}$ Both systems developed in ways that serve the same functional need ${ }^{176}$ : both evolved to permit sub rosa consideration of the dangerousness of the defendant. But the two systems serve that function in ways that are alien to each other, and alienating as well.

\section{Mercy or Exculpation?: The Modern Divergence}

Many of our differences thus took shape by 1870 . Nevertheless we must carry the story into the twentieth and twenty-first centuries to get a full sense of how the "generally accepted [American] ideology of a presumption of innocence" sets our system of criminal justice apart from those of the Continent. ${ }^{177}$ For if the continental systems had moved strongly toward a norm of exculpation by 1870 , in subsequent decades they have swung noticeably back toward mercy.

In particular, they have swung toward the modernized forms of mercy associated with the movement sometimes called "penal modernism." Penal modernism, which swept the Western world beginning in the late nineteenth century, was a movement for the reform of criminal justice that relied heavily on the work of penologists, as well as on the work of the caring professions, psychology and social work. It came to the fore in the Western world at the same time that modern social welfare state programs came to the fore, and it had a great deal in common with them. The new social welfare state programs generally rejected nineteenth-century values of selfreliance in favor of legislation that tolerated the notion that individuals might be dependent on government to some degree. In much the same way, penal modernism departed from the nineteenth-century republican focus on culpability. The aim of penal modernism was not to declare the largest possible number of deserving offenders "innocent," thus shielding them from the punishment power of the state. On the contrary, penal modernist doctrinal teachings generally made it comparatively easy to convict. Instead, penal modernism made its distinctions in the punishment process, preaching the creation of tailored treatments for different defendants"individualized" punishments that would take account of the individual

175. It is important to observe that conspiracy law in particular serves this end by loosening the evidentiary restrictions on the admission of statements of coconspirators. See FED. R. EVID. $801(d)(2)(E)$.

176. This is an example of functional analysis in comparative law, as advocated by Konrad Zweigert and Hein Kötz. See generally KONRAD ZWEIGERT \& HEIN KöTZ, INTRODUCTION TO COMPARATIVE LAW (Tony Weir trans., $3 d$ ed. 1998).

177. Packer, supra note 1 , at 11. 
susceptibility to rehabilitation or, as the case might be, their irremediable individual dangerousness. All of these modernist methods assumed that a healthy criminal justice system was one in which the state took charge of the largest number of offenders possible. ${ }^{178}$

In that sense, penal modernism was the inheritor of the traditions of princely mercy of the eighteenth century. ${ }^{179}$ Princely mercy focused on the offender, not the offense, and it put comparatively diminished emphasis on culpability, instead convicting most defendants while taking a broader perspective on the prior history and way of life of the convict who pled for mercy. ${ }^{180}$ Penal modernism also focused on the offender and took a broader perspective on his history and way of life. ${ }^{181}$ The critical difference between the penal modernist approach and the mercy approach of the eighteenth century was that penal modernism, instead of founding its "individualized" decision making on sentiment, founded it on psychology, penology, and social science. ${ }^{182}$ The deep kinship with the old mercy approach was there, though: to an important degree, penal modernism had exactly the "neo-feudal" cast that critics ascribed to the social welfare state. $^{183}$

During the first two-thirds of the twentieth century, penal modernism had a profound influence in America and Europe alike. This was a period of relative convergence in the criminal justice of the Atlantic world, just as it was a period of relative convergence in progressive taxation and social welfare state policies. Penal modernist doctrines affected the America of the Model Penal Code just as they affected progressives and fascists in Europe. Over the last forty years or so, however, the pattern of divergence has reasserted itself; today we see an American system that has moved much more strongly toward exculpation, while in continental Europe, mercy, especially in its penal modernist incarnation, has maintained its strength, and even grown in strength.

The most striking example of the continuing growth in strength of the mercy approach on the Continent comes from France. During the socialist regime of François Mitterand, France became the scene of a notable experiment in modern criminal justice, the Nouveau Code Pénal, which entered into effect in 1994 (and which has since attracted much less

178. See Whitman, supra note 124, at 144 (describing the penal modernist argument as one that advocated for individualized punishment and rehabilitation).

179. See id. at 157-58 (detailing how penal modernist judges are compelled to look beyond single acts to determine the character of an individual).

180. See id. at 156-57 (describing the emphasis penal modernism places on considering the past life, health, habits, conduct, and mental and moral propensities of an offender).

181. Id. at $156-57,160$.

182. Id. at 153-54.

183. See id. at $158-59,180$ (describing the social welfare state and penal modernism as "paternalistic"). 
attention from scholars of comparative law than it deserves). ${ }^{184}$ As we have seen, on the Continent the exculpation revolution of the nineteenth century led to the creation of more complex doctrines of culpability, which permitted the acquittal of a larger proportion of technically "innocent" defendants. In France, in particular, it led to the creation of doctrines of circonstances atténuantes, "extenuating circumstances," on the strength of which the nineteenth-century French jury could declare the accused to be among the innocent. ${ }^{185}$

The Nouveau Code Pénal rejected that tradition, eliminating circonstances atténuantes from French criminal law two centuries after the French Revolution. ${ }^{186}$ Instead, the new Code was designed to shift the weight to the punishment decision, essentially entrusting the assessment of any excuses the offender might offer to the judgment of punishment professionals. ${ }^{187}$ It did not do this, however, in a purely penal modernist way, nor in a way that simply replicated the old practices of princely mercy: the offender was not simply delivered into the hands of psychologists, social workers, and penologists-as is still the case in Germany, for example. Instead, the Nouveau Code Pénal was designed to juridify the punishment process, by vesting the supervision of the offender in a juge de l'application des peines, a "judge of the application of punishments," seized of the case upon conviction and called upon to watch over the offender's progress. ${ }^{188}$ The aim was to tame the older styles of punishment, whether founded in clemency or in psychology, subjecting them to a sterner rule of law. The bottom line, though, was that the French criminal justice system shifted away from the nineteenth-century logic of culpability, with its drive

184. Comparative Criminal law Project, The French Penal Code of 1994 as AMENDED AS OF JANUARY 1, 1999, at 1 (Edward A. Tomlinson trans., 1999).

185. For an account of their use in French legal history, see JAMES M. DONOVAN, JURIES AND the TRANSFormation of CRIMINal Justice IN FranCe in the Nineteenth \& TWENTIETH CENTURIES 5-6, 56-57 (2010).

186. Id. at 8-9.

187. RASSAT, supra note 84 , at 761 ("Jusqu'au nouveau Code pénal, toutes les juridictions de jugement pouvaient absoudre la personne poursuivie s'il constatait l'existence d'une excuse absolutoire. Cela n'est plus possible aujourd'hui bien que le Code pénal ait laissé subsister en pratique ces excuses.... [Before the new penal code, all trial courts could acquit the accused person if there was an absolving excuse. This is no longer possible today although the penal code has allowed such excuses to remain in practice .... ."); see also COMPARATIVE CRIMINAL LAW PROJECT, supra note 184, at 8-9.

188. The juge de l'application des peines has a long and evolving history in French criminal procedure. This is not the place to discuss it in full. See MARTINE HerzoG-Evans, DroIT DE L'APPLICATION DES PEINES $\S \S 21.11-12,21.21-24$ (2d ed. 2005) (discussing the role of the judge of application of punishments before and after the presumption of innocence was instituted). See generally id. at $92-110$. 
to classify a larger number of defendants as "innocent." Instead the Nouveau Code Pénal tended to make declarations of "guilty" easier, maximizing the number of offenders placed under the control of the state punishment system.

During the same period, American criminal law took the opposite tack. From the mid-1970s onward, the United States showed, as we all know, a much sharper reversal of social welfare state practices than was witnessed in continental Europe. (The contrast is nowhere stronger than in the divergence between the policies of the governments of Ronald Reagan and François Mitterrand, both of whom took office in 1981.) ${ }^{189}$ Criminal justice moved in a direction parallel to the movement of the rest of American law. What that meant was a large-scale reaction against penal modernist policies, and in favor of a return to the culpability calculus. ${ }^{190}$ Determinate sentencing is the most important product of this American renaissance of culpability. The shift to culpability did not end with determinate sentencing, though. Recent years have also seen a growing tendency in Supreme Court jurisprudence to extend the logic of culpability into the sentencing phase: there is an ever-stronger drive in American law to insist that sentences should depend only on the measure of the offender's guilt for the act committed, not on other sentencing factors. ${ }^{191}$

\section{VIII.Sentencing Practice: Mercy or Rigor?}

With that we come to the law of sentencing, an area in which the presumption of mercy makes itself felt with particular force, and in which we find some particularly dramatic contrasts between contemporary American law and contemporary continental law.

Continental sentencing law remains oriented toward mercy. To some extent, this involves a literal continuation of pre-nineteenth-century practices. Grace still survives: modern continental republics are the successors to premodern continental monarchies, and their exercise of state power still sometimes resembles historic monarchical practices. Until quite recently, for example, the Italian Ministry of Justice was called the Ministry of Grace and Justice; just as the main office charged with criminal justice

189. See Christian SAINT-ETIENNE, THE MitTerRand and REAGan ECONOMIC EXPERIMENTS: A LESSON IN POLITICAL ECONOMY 15-18 (1985) (explaining that the French government played a much more prominent role in economic and social affairs than its American counterpart).

190. See Whitman, supra note 124 , at 145 (indicating that penal modernism began falling into disrepute as tough-on-crime politics grew more prominent).

191. For developments in the Supreme Court since Apprendi v. New Jersey, 530 U.S. 466 (2000), and a characteristic contemporary American argument (deeply misguided, I believe) in favor of limiting sentencing to facts established in the guilt phase under standard culpability calculus and procedure, see generally Carissa Byme Hessick \& F. Andrew Hessick, Procedural Rights at Sentencing, 90 NOTRE DAME L. REV. 187 (2014). 
policy making in France is still the "Office of Criminal Affairs and Acts of Grace." 192 Clemency continues to play an active part in the administration of continental punishment. One notable recent example is Jérôme Kerviel, the rogue trader who lost 4.9 billion Euros for Société Générale, and who subsequently made himself a small-scale cultural hero in France by attacking the world of finance. While Kerviel was on a walk of penance through Italy after meeting with the Pope, on his way to surrender himself for imprisonment in France, the French government, under political pressure, hinted it might consider offering him a pardon. (He refused to petition for a pardon; was imprisoned; and then was promptly released as a result of French sentencing norms.) ${ }^{193}$ A great deal of pardoning goes on in other circumstances as well.

But most of the practice of mitigation in contemporary continental punishment does not involve the literal grant of grace. There are many formal legal rules mitigating punishment. There are presumptive limits on the execution of punishment itself. For example, there are presumptions that persons sentenced nominally to life in prison will serve only a shorter term, say of fifteen or eighteen years. ${ }^{194}$ There are presumptions against imprisonment: where at all possible, offenders are supposed to be fined, required to do community service, be subjected to house arrest, or suffer some suspension of privileges. ${ }^{195}$ There are practices of mercifully cutting sentences for those who seem to lead deserving lives even though they are guilty of a criminal act. ${ }^{196}$ (We have already seen that Amanda Knox

192. Direction des affaires criminelles et des grâces, MINISTÉRE DE LA JUST. (Sept. 15, 2010), http://www.justice.gouv.fr/le-ministere-de-la-justice-10017/direction-des-affaires -criminelles-et-des-graces-10024/ [http://perma.cc/J923-YH8E].

193. John Lichfield, Rogue Trader Jérôme Kerviel 'to Surrender' to French Police After Protest March Through Italy, INDEPENDENT (May 18, 2014), www.independent.co.uk/ news/world/europe/rogue-trader-j-r-me-kerviel-to-surrender-to-french-police-after-protest-march -through-italy-9392639.html [http://perma.cc/BD6D-7RTM]; Kim Willsher, French Rogue Trader Jérôme Kerviel Freed, GUARDIAN (Sept. 4, 2014, 11:43 AM), http://www.theguardian.com/ business $/ 2014 / \mathrm{sep} / 04 /$ french-rogue-trader-jerome-kerviel-freed-prison-socite-generale [https://perma.cc/E6HJ-EPWQ].

194. For Germany (15 years), STGB, supra note $46, \S \S 38,57 \mathrm{a}$; for France (18 years), C. PÉN., supra note 51, art. 132-23; for Italian practice, see Appendix, infra. These are again simply presumptions, which may be varied; France recently saw its third defendant sentenced to what is theoretically the possibility of a true life sentence. See Nicolas Blondiau, 3e homme comdamné à la perpétuité incompressible, LE FIGARO (Jan. 31, 2015, 12:46 PM), http://www.lefigaro.fr/ actualite-france/2015/01/31/01016-20150131ARTFIG00068-nicolas-blondiau-3e-homme-

condamne-a-la-perpetuite-incompressible.php [http://perma.cc/G86R-VZH6]. There is also European Court of Human Rights jurisprudence requiring consideration of parole after a certain number of years, which I do not discuss here. See Vinter v. United Kingdom, 2013-III Eur. Ct. H.R. 317.

195. HERZOG-EVANS, supra note $188, \S 81.12$ (the objective "est d'éviter l'incarcération des condamnés [is to avoid the imprisonment of convicted persons]"); WHITMAN, supra note 45, at 10; Hörnle, supra note 101 at 190-96 (surveying German punishment law).

196. See, e.g., STGB, supra note $46, \S 46$ (requiring consideration of circumstances that weigh for and against the offender- "Umstände, die für und gegen den Täter sprechen"). 
benefited from such a practice in Italy.) These are all merely presumptions - they do not necessarily dictate milder sentencing in every case. (In particular, left-wing critics worry that there is too much reluctance to release offenders sentenced to life. $)^{197}$ But they are presumptions and practices that are taken seriously in Europe and that regularly result in mitigation. The tendency is strong to announce a stern nominal sentence, as a way of expressing public condemnation of the offense committed, while leaving room for mercy for the individual offender.

These merciful continental approaches to the execution of punishment are sharply at odds with contemporary American punishment practice. In America too, there were once informal presumptions that convicted persons would serve only some portion of their sentence. But these belonged to the now-vanished era when policies of individualization permitted prison officials discretion in determining when to release offenders. ${ }^{198}$ The determinate sentencing movement that swept the United States beginning in the mid-1970s undermined those policies. The passage of "truth in sentencing" laws effectively eliminated continental-style presumptions of mercy. ${ }^{199}$ There is no presumption against imprisonment in American law either-although the fiscal and moral crisis of mass incarceration has been driving Americans to adopt a presumption against imprisonment at least for nonviolent offenders. ${ }^{200}$ As for pardoning: the cultural tradition of hostility to the pardoning power runs very deep in America; ${ }^{201}$ certainly it continues to stir anger as President Obama sets out to revive a meaningful executive clemency practice. ${ }^{202}$

\section{Conclusion: Toward an American Presumption of Mercy?}

The picture in all of these areas of criminal law is much the same, whether the subject is the structure of the trial, the use of criminal law theory, or the norms of sentencing law. The great contrast between the United States and continental Europe is not the contrast between an adversarial tradition respectful of defendants' rights and an inquisitorial one committed only to ruthlessly hunting down the truth. Both traditions are respectful of defendants' rights. The real contrast is between one tradition

197. E.g., Andreas Bernard, Lebenslänglich, SÜDDEUTSCHE ZEITUNG (Ger.), http://sz -magazin.sueddeutsche.de/texte/anzeigen/3383/Lebenslaenglich [http://perma.cc/5EYC-9Y95].

198. Ely Aharonson, Determinate Sentencing and American Exceptionalism: The Underpinnings and Effects of Cross-National Differences in the Regulation of Sentencing Discretion, LAW \& CONTEMP. PROBS., no. 1, 2013, at 161, 172-73.

199. For a sustained study of the contrasts, see generally $i d$.

200. Melissa Hamilton, Prison-by-Default: Challenging the Federal Sentencing Policy's Presumption of Incarceration, 51 HoUS. L. REV. 1271, 1272, 1313, 1321 (2014).

201. For the current state of play before the Supreme Court, and an admirable effort to promote clemency in American law, see generally Barkow \& Osler, supra note 5.

202. E.g., Robinson, supra note 6. 
driven by a more or less libertarian fear that rogue government officers will target innocent persons, and another generally respectful of the authority of professional law enforcement personnel, but determined to keep the practice of punishment within decent, civilized limits. The contrast is between one tradition that puts all the weight on safeguards for the innocent, and another that reserves much of its compassion for the guilty.

Can we learn anything from the traditions and practices of continental mercy as we struggle with the current crisis of harsh justice in America? It would certainly be wrong to suggest that we could simply switch to doing things the continental way. Societies do not have the option of picking and choosing among legal traditions. Both of these modes of justice are too deeply rooted in cultural and political traditions to be casually displaced. In particular, there is no plausible hope that inquisitorial practices could be transplanted wholesale into the United States. The continental values I have described are too alien to American culture. They rest on a tradition of trust in government that Americans often viscerally reject. They assume deference to the "scientific" expertise of jurists where Americans believe that lay democracy should rule. They reflect traditions of hierarchical mercy against which Americans commonly chafe.

Perhaps most of all, the continental approaches start from a tacit assumption that Americans find both obnoxious and dangerous: that accused persons are ordinarily guilty. The American commitment to maintaining a just system of criminal law is a commitment to combatting one particular nightmare scenario: the scenario of the conviction of the innocent. It would not be easy for us to shift to combatting something else. As a matter of logic, it is of course perfectly possible to have both a presumption of innocence and a presumption of mercy. Indeed I have argued here that continental law has both. Nevertheless, the life of the criminal law has never been logic. The life of the criminal law has been anxieties, panics, nightmare scenarios, and beliefs that there is some pressing evil afoot that must be met with stern measures.

For all those reasons there is no prospect that the strong continental orientation toward the presumption of mercy will establish itself in America. Moreover, there is a good case to be made that America ought to have a stronger orientation toward the presumption of innocence, or at least a somewhat stronger orientation, than continental Europe does. The culture of continental criminal justice rests on faith in the professional trustworthiness of officials-and by and large, continental European officials probably are more trustworthy than American ones. We will never know how many innocents have been convicted in any country, but it is a fair bet that there are more falsely convicted people in American prisons than in French, German, Swedish, or Dutch ones. With that in mind, we might reasonably conclude that we simply need our "generally accepted 
ideology of a presumption of innocence" more than our continental cousins do. A powerful presumption of innocence is a necessity in a country with an amateurish, aggressive, fragmented, and all too frequently politicized justice system.

Still, we would be less than decent human beings, and less than thoughtful lawyers, if we were not at least a little shaken by our encounter with systems more oriented toward the presumption of mercy. Certainly when we look at the bottom line - the basic measures of cruelty and harshness that ought to be the test of any civilized criminal justice systemAmerica does not come off well. We trumpet our presumption of innocence to the world, but at the same time our own system of criminal punishment is out of hand. Mass incarceration and other aspects of penal harshness are among the most depressing and frightening features of contemporary American life-a great stain on the record of our national experiment. It is no justification for the harshness of our system to declare that we are committed only to punishing the guilty. Even if there were not a single wrongly convicted person in our country, something would be fearfully amiss. Our national commitment to the presumption of innocence, dearly held though it is, has done nothing to tame the worst evils of the contemporary American punishment system. For that reason alone, decent Americans should be eager to reflect on the practices of neighbors who show a deeper concern for the presumption of mercy.

And there are glimmers of hope that American justice can find its way to its own practices of mercy. The sense of crisis is powerfully present in America, and President Obama's highly visible resort to the clemency power has forced at least the beginnings of a public debate. Meanwhile, we do have some doctrinal resources that could be exploited in building an indigenous American approach to more merciful justice. As Rachel Barkow has wisely argued, death penalty jurisprudence may point the way to a changed attitude toward sentencing. The decision to put an offender to death makes us profoundly uneasy, and the Supreme Court has held that jurors in the sentencing phase must consider a wide range of character evidence: there is a "requirement," as the Court declared in 2012, "of individualized sentencing for defendants facing the most serious penalties." ${ }^{203}$ Barkow proposes that death penalty jurisprudence could offer a model for our criminal law more broadly, and she is right ${ }^{204}$ : if we can acknowledge that long prison sentences too are "serious penalties," we can grasp some of the imperative of mercy even outside the terrors of the realm of death. The American Bar Association too has called for prosecutors to

203. Miller v. Alabama, 132 S. Ct. 2455, 2460 (2012).

204. Rachel E. Barkow, The Court of Life and Death: The Two Tracks of Canstitutional Sentencing Law and the Case for Uniformity, 107 MICH. L. REV. 1145, 1147-51 (2009). 
individualize the treatment of offenders. ${ }^{205}$ And as this Article suggests, we can embrace such forms of more individualized, more merciful justice without being unfaithful to the historic ideals of the American Republic. Our familiar forms of criminal trial do not date back to the era of founding; and they certainly do not date back to the origins of the common law. They are not found in the text of our Constitution. They are a creation of our nineteenth-century predecessors, and we have as much right as they did to take a creative approach to our law in the service of the demands of justice.

In any case, we arguably have no choice but to look beyond our familiar American way of doing things: our mode of justice is facing a gathering crisis caused by the rise of modern scientific investigation. The American common law system is all about evidentiary uncertainty: it turns on the assumption that we can deny ourselves knowledge of guilt-tying ourselves to the evidentiary mast, as it were. Our Fourth Amendment and our law of evidence contribute to the same end: they allow us to put evidentiary "obstacles" in the way of proving guilt. Yet modern technology is flooding us with so much information that there are fewer and fewer cases in which we can feel comfortable forcing ignorance upon ourselves. The same DNA evidence that has revealed false convictions through the work of the Innocence Project is available in modern investigations; ${ }^{206}$ more and more frequently we have knowledge where our ancestors only had guesses. There are electronic data trails. ${ }^{207}$ There are cell phones and security cameras. We live in the astounding age in which the Boston Marathon Bombers, and many others, have actually been filmed in the act. $^{208}$ Increasingly, police officers are carrying wearable cameras. Encounters between the police and citizens that would once have been ignored, forgotten or hushed up are now broadcast on YouTube. ${ }^{209}$ No generation before ours has ever had to cope with so much knowledge.

This rising flood of information is slowly, but inevitably, swamping our American mode of justice. We have entered the age of certainty, while our inherited sense of the limitation of state power requires the systematic

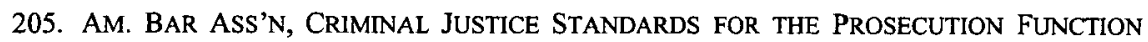
3-7.3 (4th ed. 2015), http://www.americanbar.org/groups/criminal_justice/standards/

ProsecutionFunctionFourthEdition.html [https://perma.cc/48D6-B7FY].

206. Paul E. Tracy \& Vincent Morgan, Big Brother and His Science Kit: DNA Databases for 21st Century Crime Control?, 90 J. CRIM. L. \& CRIMINOLOGY 635, 636, 641-42 (2000).

207. For their role in the Knox trial, see Mirabella, supra note 33, at 244-45.

208. Erin Burnett, Newly-Released Video of Boston Marathon Bombing, CNN: OUTFRONT (Mar. 9, 2015, 6:48 PM), http://www.cnn.com/videos/us/2015/03/09/erin-dnt-feyerick-boston -marathon-bombing-never-before-seen-video.cnn [https://perma.cc/64P9-NA6R] (displaying a video released by the U.S. Attorney's Office showing one of the bombers walking away just as the first bomb goes off).

209. See, e.g., Wall Street Journal, Raw Footage: Texas Cop Draws Gun on Pool-Party Teens, YOUTUBE (June 8, 2015), https://www.youtube.com/watch?v=z6tTfoifB7Q [https:// perma.cc/4TLJ-TK53]. 
creation of uncertainty. It is too much to ask that law enforcement ignore the wealth of available information. The Supreme Court, and commentators like Professor Schulhofer, are struggling manfully to hold off the flood, maintaining some sort of meaningful Fourth Amendment jurisprudence that can serve as our foundation for the American mode of limiting state power. Justice Scalia in particular warned that we must work to prevent the erection of a "genetic panopticon."210 But we will not be able to play King Cnut forever, marching out to fight off the sea of modern knowledge with the antique sword of our criminal procedure. If we want to have a just criminal justice system, we are going to need an alternative conception of how to put limits on the state. We are going to have to find a way to recognize that there can be meaningful rights even in a "panopticon" world in which we know with certainty that defendants are guilty.

And therein lies the most important lesson we can learn from reflecting on inquisitorial practice: The continental countries are not "police states," but their idea of justice is ultimately different from ours, and understanding their idea of justice can help us to understand what we most need to understand-that there can be rights even in a panopticon. Even a state that knows everything about us can be kept in check if the criminal justice system insists on rights and protections for the guilty.

Rights and protections for the guilty are what the Continent has and what we lack. We must make the effort to see the inquisitorial approach on its own terms and in light of its own values, so that we can have some hope of learning from it. We are certainly not going to embrace full-scale inquisitorial justice in America. The point of comparative law, however, is not to engineer wholesale institutional transplants, but to broaden the mind - to help us to escape the conceptual cage of our own tradition. In this case, the point is to help us to recognize that the preservation of liberty against the investigative state is not the only possible foundation for a just and free system of criminal justice. We can think differently-and that matters a great deal, because in the modern world we are going to have to think differently. 


\section{Appendix \\ The Amanda Knox Case}

No continental criminal prosecution has ever riveted American attention like the case of Amanda Knox, which ended in March 2015 when her murder conviction was dramatically and unexpectedly overturned by the Italian Supreme Court. ${ }^{211}$ In particular, there is no case that has stirred more American sentiments of rage and distrust toward continental justice, much of which has been described in an excellent student note by Julia Grace Mirabella, who gives a sensitive review of most of the key differences between Italian and American justice. ${ }^{212}$ Widespread American familiarity with the Knox case makes it an ideal subject for an Article aimed at the American audience, and in this Appendix, following Mirabella's lead, I will use the events of the Knox prosecution as a way of illustrating, and probing more deeply, the problems in comparative law that are my topic in this Article.

Knox was tried by an Italian court system that has been in great flux. Italian justice has long been plagued by problems, notably long delays in delivering final judgments, and in 1988 Italian criminal procedure was the subject of a major reform intended to introduce adversarial practices borrowed from the culturally prestigious American common law. ${ }^{213}$ That reform did not progress smoothly; years of conflict between the Italian Supreme Constitutional Court, the Italian Parliament, and the Italian judiciary ensued. ${ }^{214}$ The net result, after a decade and a half of intermittent turmoil, is a system that everybody agrees is some sort of hybrid between adversarial and inquisitorial and that nobody (as far as I know) regards as fully successful.

It is important to review some of the details of the 1988 reform. The reform was intended to bring more efficiency to Italian justice, and in particular to pare down delays. That may sound mysterious: why would anybody think that introducing adversarial practices would speed up the trial process? (The same question can be asked of Poland, which introduced similar adversarial reforms with the same goal in 2015. $)^{215}$ The

211. Elisabetta Povoledo, Amanda Knox Acquitted of 2007 Murder by ltaly's Highest Court, N.Y. TIMES (Mar. 27, 2015), http://www.nytimes.com/2015/03/28/world/europe/amanda-knox -trial.html?_r=0 [https://perma.cc/26KZ-ZRDE].

212. Mirabella, supra note 33 , at $241-47$.

213. Elisabetta Grande, Italian Criminal Justice: Borrowing and Resistance, 48 AM. J. COMP. L. $227,228-32(2000)$.

214. See Pizzi \& Montagna, supra note 64 , at $447-65$ (describing the reactions to the 1988 reform by the Italian Supreme Constitutional Court, the Italian Parliament, and the Italian judiciary).

215. Marion Isobel, Case Watch: European Court Pushes Poland to Speed Up Wheels of Justice, OPEN SOC'Y FOUND. (July 9, 2015), https://www.opensocietyfoundations.org/voices/ case-watch-european-court-pushes-poland-speed-wheels-justice [https://perma.cc/84XN-ZSX2]. 
answer is that Italians were attracted by the American conception of the purpose of the trial that I described above. Americans conceive of the trial as serving a banal fact-finding purpose-the purpose of "sorting the innocent from the guilty."216 As a result, they see little to object to in mass plea bargaining, even in cases of the utmost gravity. They even tolerate the imposition of life sentences through a plea bargain. ${ }^{217}$ By contrast, the continental world has traditionally viewed the trial as serving purposes that go beyond fact-finding: the purpose of conscientiously weighing the proper sentence and the purpose of giving the proper solemn ritual character to the rite de passage of a criminal conviction. ${ }^{218}$ From that point of view it seems imperative that trials be held even for offenders whose guilt is obvious.

The Italian reformers of the late 1980s blamed the continental mentality for the defects of their system. They believed that the "ritual" of trial was being conducted in too many cases-that their legal system was staggering under the weight of too much solemn continental formality. ${ }^{219}$ The attraction of the American system was that it seemed to take a more nononsense approach to justice, permitting the quick and comparatively informal resolution of cases through plea bargaining. So they Americanized. That does not mean that they were ready to embrace American justice without qualm. Like other Europeans, the Italians could not accept the notion that even life sentences and other serious penalties could be imposed without the care and ritual formality of a trial. When it came to the most serious cases, they, like other continentals, insisted on the necessity of a full-dress trial. Nevertheless, the overall aim was to speed Italian justice up by shaking up the pious Italian belief that justice always required a proper "ritual." As the principal draftsman of the new Code of Criminal Procedure explained in 1988, the reform was intended to "demythify" the trial, putting an end to the idea that solemnities were always necessary. ${ }^{220}$ Many defendants would be dispensed from the full rite of a

216. Samuel R. Gross, Pretrial Incentives, Post-Conviction Review, and Sorting Criminal Prosecutions by Guilt or Innocence, 56 N.Y.L. SCH. L. REV. 1009, 1010 (2011/12).

217. E.g., Marc Freeman, Delray Felon Pleads Guilty, Gets 3 Life Sentences for Murders of Ex-girlfriend, Children, SUN SENTINEL (Jan. 8, 2016, 1:34 PM), http://www.sun -sentinel.com/local/palm-beach/fl-clem-beauchamp-murder-plea-deal-20160108-story.html [https://perma.cc/QYF9-SHUT]; see also McCoy, supra note 109, at 73-74 (describing that plea bargaining for serious criminal cases began in the mid-nineteenth century and in $2005,96 \%$ of felony cases were concluded through guilty pleas).

218. Monica Eppinger, Reality Check: Detention in the War on Terror, 62 CATH. U. L. REV. $325,346-47$ (2013).

219. William T. Pizzi \& Luca Marafioti, The New Italian Code of Criminal Procedure: The Difficulties of Building an Adversarial Trial System on a Civil Law Foundation, 17 YALE J. INT'L L. 1, 5-6 (1992).

220. Giovanni Conso, Verso il Nuovo Processo Penale, 1988 La Giustizia Penale I 289, 293 ("[L]a smitizzazione del dibattimento ...."). 
traditional trial. For them there would instead be new "rituals," including summary process offering lightened sentences and an Italian version of plea bargaining. ${ }^{221}$

With regard to serious matters, though, trial was still to be held, and it was still to be held largely in its traditional form. The reform certainly wrought some fundamental changes in trial. In particular, it aimed to transform the role of the trial judge, who was to play a more passive role in a system driven much more by adversary counsel. ${ }^{222}$ Nevertheless, in critical respects the reform stayed faithful to continental tradition: It did not introduce common-law bifurcation of the trial into guilt and sentencing phases, and it retained the practice of mixed deliberation by judges and jurors together. As Elisabetta Grande explains the reform:

A single body of adjudicators-consisting of professional judges, that in the most serious cases sit together with lay assessors-[still] passes on issues of law as well as fact. Thus, no distinction between judge and jury as two adjudicating bodies can be made. Moreover, the same unitary adjudicating body determines both guilt and sentence. As a result, the trial does not have to be bifurcated into a first hearing devoted solely to the issue of guilt, and a subsequent second hearing dealing with the sentence. ${ }^{223}$

Thus, despite the Italian reform, Amanda Knox was tried in the standard variant of a continental court.

In other respects too, the reformers left standard continental practices in place. In particular, they did not eliminate the practice of staging repeated de novo appellate review. The appellate process is one of the features that sets continental justice most sharply apart from the common law. The common law permits only extremely limited appellate review in criminal matters. In a tradition stretching far back into the Middle Ages (indeed into early medieval trial by combat), the common law does not ordinarily permit the state to appeal

221. Id. at 292 ("Vi sono i riti predisposti per evitare il dibattimento, come il giudizio abbreviato, il cosidetto patteggiamento ed il procedimento per decreto penale, mentre vi sono quelli che anticipano il dibattimento. [There are proceedings designed to avoid the trial such as: summary judgments, plea bargain and ex parte criminal proceedings, while there are those that anticipate it.]"); see also Codice di procedure penale [C.p.p.] [Code of Penal Procedure] art. 444 (1988) (It.) (permitting a "guilty plea" application for a one-third reduction in applicable sentence, provided that, after reduction, an imprisonment sentence does not exceed five years); $i d$. art. 442 (providing for an "abbreviated trial" with a one-third reduction in applicable sentence upon conviction).

222. The consensus is that judges have nevertheless reclaimed much of the historic authority, arrogating to themselves the authority to introduce and consider evidence as required by their Aufklärungspflicht. See Pizzi \& Montagna, supra note 64, at 448-49 (arguing that Italian judges feel more personally responsible for reaching an accurate and just result and have thus sought to recapture their traditional role in the fact-finding process).

223. Grande, supra note 213 , at 228. 
acquittals, ${ }^{224}$ and of course there is never de novo review, since fact-finding must be done by the trial-level fact finder. The Continent, by contrast, brings its bureaucratic "audit" mentality to the appellate process. ${ }^{225}$ In order to avoid mistakes of both fact and law, continental law calls for repeated vetting of the case both before and after the trial. This too matters for Knox: Her initial conviction was overturned on one de novo appeal in 2011, only to be reinstated in a second in 2014 before it was finally overturned again. 226

Not least, the reform left the fundamental orientation toward mercy that I have described in place. Italian justice retains its sense of a "paternalistic obligation to protect the defendant," ${ }^{, 227}$ and standard merciful practices were never eliminated in Italian sentencing law, trial management, and postconviction administration.

So the 1988 reform and the subsequent changes, whatever their merits or demerits, did not by any means introduce the whole package of American practices into Italian criminal procedure, and the Knox matter remains a useful vehicle for examining the virtues and dangers of the continental tradition.

I have already spoken, in the body of this Article, of some of the virtues: The trial court was obligated to consider extenuating offender characteristics, and it did so, finding that Knox, despite her guilt for the offense charged, was studious, a dependable employee, and too young and too far from home to be subjected to a punishment untempered by mercy. (It is worth pausing for a moment over those findings. Continental law often emphasizes studiousness and good work habits. When the trial court looked favorably on Knox, it was because she did not engage in the sort of behavior that continental courts typically condemn: She did not "play hooky from school" or "skip out on work."228 As this suggests, one question that preoccupies continental consideration of extenuating offender characteristics is whether the

224. At issue is a fundamental contrast between common law and continental understandings of the nature of double jeopardy. The continental tradition has a strong commitment to a version of the ban on double jeopardy that falls under the Latin rubric ne bis in idem. However, the continental tradition regards de novo appeal simply as one stage in a multistage consideration of the merits of the case, inevitably and naturally including careful bureaucratic appellate review. By contrast, the common law tradition, with its roots in medieval trial by combat, deems the trial, originally understood to be a judgment of God, as a definitive resolution of the matter: A "jeopardy," literally a jeu parti, a "game of even chances," is a combat wager. For the early medieval background, see JAMES Q. WHITMAN, THE VERDICT OF BATTLE 80-81 (2012).

225. Irene M. Ten Cate, International Arbitration and the Ends of Appellate Review, 44 N.Y.U. J. INT'L L. \& POL. 1109, 1141-42 (2012).

226. David Cutler \& Bill Rigby, Timeline: Amanda Knox Acquitted of Murder, Ending YearsLong Saga, REUTERS (Mar. 27, 2015, 8:31 PM), http://www.reuters.com/article/us-italy-knox -events-idUSKBNOMO01520150328 [https://perma.cc/DJT6-C49S].

227. Pizzi \& Montagna, supra note 64 , at 449.

228. Granderath, supra note 28, at 320 ("Schuleschwänzen, Weglaufen vom Arbeitsplatz, Vernachlässigung der Familie, fortgesetzter Alkholmißbrauch oder eine sonstige tadelnswerte Lebensführung im Zumsammenhang mit der Tat. [Truancy, absconding from work, family neglect, continued alcohol abuse or other reprehensible lifestyles in connection with the crime.]"). 
defendant is a dependable worker who can be integrated into a modern economy.) The trial court's findings of those extenuating characteristics were affirmed by the January 2014 appellate judgment that reinstated her conviction. To that extent, Knox benefited from Italian mercy.

Nevertheless, her nominal sentence was not light: The trial court announced a sentence of twenty-six years; the 2014 appellate judgment extended it to twenty-eight and a half years. ${ }^{229}$ Those nominal sentences are comparable to the sentences an American offender might receive; when we read about them we might think there is not much to Italian mercy. But before we gasp at Knox's sentences, we should understand how they were arrived atand how extremely unlikely it is that she would ever actually serve her full term.

The length of the nominal sentences reflected the fact that both courts found that there were aggravating circumstances that balanced the extenuating factors. ${ }^{230}$ The nature of those aggravating factors deserves some attention. The trial court, as we shall see, based its judgment on an improbably lurid account of Knox's sexual life, along with lurid speculation about the sexual excitement she triggered in others. In line with its sex-focused take on the case, the trial court found that her sentence should be extended because the murder was associated with a supposed sexual offense. ${ }^{231}$ The 2014 appellate court, by contrast, took a different view of the aggravating circumstances. Rejecting the sexual speculations of the initial judgment, the 2014 judgment extended Knox's sentence because of what it found to be her efforts to cover up the crime, in particular because she and her boyfriend spent hours scrubbing down the crime scene, along with her attempts to deflect police attention from herself by falsely accusing her employer, an unfortunate African immigrant named Diya Lumumba, whose hard-won life in Perugia was ruined by her accusation. ${ }^{232}$

That 2014 account of the aggravating circumstances is of real interest for my topic, and it is worth dwelling on it. The 2014 court sentenced Knox to an aggravated sentence because she failed to adopt a course that a system strongly oriented toward mercy can be expected to reward: she did not admit her guilt and throw herself on the mercy of the justice system. ${ }^{233}$ It is important to

229. Cutler \& Rigby, supra note 226.

230. Sentenza della Ass. App., 29 aprile 2014, n. 9066/07 R.N.R., at 331 (It.), http://www.pengiamurderfile.org/download/nencini/nencini_motivazioni_2014-04-

29_searchable.pdf [https://perma.cc/73KC-VSLJ]; Sentenza della Corte d'Ass., 4 marzo 2010,

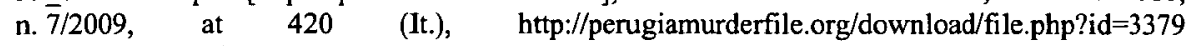
[https://perma.cc/QB7F-SCGV].

231. Sentenza della Corte d'Ass., n. 7/2009, at 419-20.

232. Id.

233. See Rachel Donadio, U.S. Student Delivers Appeal at End of Italian Trial, N.Y. TIMES (Dec. 3, 2009), http://www.nytimes.com/2009/12/04/world/europe/04italy.html [https://perma.cc/ 3M2Y-K9ZB] (noting that Knox refused to admit wrongdoing during her first trial). 
recognize how much she would have benefitted if she had done so. In that case, she could have taken advantage of the same merciful option taken by the third defendant in the case, Rudi Guede. Guede submitted to the rito abbreviato, the "shortened ritual," giving up his right to a full-scale trial. ${ }^{234}$ As a result, he was rewarded with an abbreviated sentence of sixteen years. Guede is a small-time thief, a thoroughly unsympathetic defendant whose case did not offer any of the extenuating offender characteristics from which Knox profited. We may assume that if Knox had submitted to the authorities and admitted guilt, she would have received a nominal sentence of significantly less than the sixteen years given to Guede. There is a great deal of mercy to be had from the Italian system; but, like mercy everywhere, it is largely for those who do not display defiance toward the state.

In any case, regardless of her nominal sentence, it is highly unlikely that Knox would ever have served the full term to which she was formally sentenced. Italy, unlike the United States, does not have "truth in sentencing" laws. On the contrary, there is a statutory presumption that offenders will not serve out their nominal sentence, and it is normal in Italy to release offenders after some portion of their sentence has been served. That is true even of notorious offenders like Mehmet Ali Ağca, the attempted assassin of Pope John Paul II, who was sentenced nominally to life in prison but released in 1999 after only nineteen years. ${ }^{235}$ Nominal sentences announce the gravity of the offense to society and the offender, the actual service of sentence is governed by norms of mercy.

Did the continental approach prove a failure in the Knox case in revealing ways? Yes indeed. There are two principal respects in which the Italian criminal justice system fell significantly short in my view. The first was flagged by all of the American critics of the Knox case: the trial court's consideration of character evidence ran wild, as the court wandered off into an unsubstantiated and overheated theory of Knox's sexual activities. The trial court faced the problem of explaining the link between Knox, her boyfriend, and Guede, the third defendant. The forensic evidence suggested that Guede pinned the victim's arm down with one of his hands, while inserting a finger of the other hand in her vagina, leaving traces of his DNA. Meanwhile, knives were held on either side of the victim's neck by two other aggressors, one of whom fatally stabbed her. In its effort to explain how this strange tableau of group aggression came to be staged, the trial court imagined the following succession of events: Amanda and her boyfriend were heatedly making love in

234. See Tom Kington, Court Cuts Rudy Guede's Sentence for Meredith Kercher Murder, GUARDIAN (Dec. 22, 2009, 1:32 PM), http://www.theguardian.com/world/2009/dec/22/rudy -guede-sentence-kercher-murder [https://perma.cc/CVZ8-9FN3] (stating that Guede submitted to a "fast-track trial" and received a reduced sentence in exchange).

235. Sebnem Arsu, Turk Who Shot Pope in 1981 to Be Released From Prison, N.Y. TIMES (Jan. 9, 2006), http://www.nytimes.com/2006/01/09/international/europe/09assassin.html [https://perma.cc/ZMM2-XY66]. 
her room. This created a "charged" sexual atmosphere in the apartment, and that charged atmosphere triggered a rape attempt by Guede:

Amanda and Raffaele were together at the house shortly after 11:00 and had decided to go to Amanda's room with the intention being intimate together .... Raffaele Sollecito and Amanda Knox were always very affectionate with each other when they were together... even in the police station [where they were awaiting police interviews] ... that underscored the behavior of these two young people together: they were extremely cozy with each other, they caressed each other, they kissed each other. An attitude hardly appropriate to the setting and the situation [of a police station after a murder] .... Amanda and Raffaele found themselves together in Amanda's house; they were together in her room and alone as Meredith was in her own room and Rudi, as it turns out, was in the bathroom [where he left an unflushed toilet].

It is therefore probable that Rudi, exiting from the bathroom, allowed himself to get caught up in a dangerous situation charged with sexual urgings, and yielding to his own concupiscence, sought to satisfy his own urgings by going into Meredith's room where she was alone with the door ajar.... [I]t seems the most probable hypothesis that Rudi decided on his own to enter Meredith's room, and her reaction and refusal were overheard by Amanda and Raffaele (Amanda's room was very close to Meredith's) who were disturbed and intervened, as the succession of events and their aftermath demonstrate, abetting Rudi who they had let into the house, and became themselves, together with Rudi, Meredith's aggressors and killers.

Because, then, the two young people, deeply interested in each other, culturally and intellectually curious, he on the eve of graduation, and her engrossed, decided to participate in this final act to force Meredith's will, with whom they'd had, especially Amanda, frequent and friendly relationship, until they caused her death, again and again always with an option to make a choice, and this Court cannot comprehend the choice of extreme evil that was made. It can be hypothesized that this evil choice started with consumption of intoxicating substances that evening, which was verified, as stated by Amanda." 236

236. Sentenza della Corte d'Ass., n. 7/2009, at 390-94 ("Amanda e Raffaele, giunti nella casa poco dopo le 23,00 è da ritenere che si siano portati nella camera di Amanda con l'intenzione di stare insieme, in intimità .... Raffaele Sollecito e Amanda Knox quando erano insieme erano tra loro molto affettuosi ... anche in Questura ... è stato evidenziato il comportamento che i due giovani ragazzi avevano: erano vicinissimi l'uno all'altra, si facevano carezze, si baciavano. Atteggiamento poco consono all'ambiente ed alla situazione.... Amanda e Raffaele che si trovavano insieme nella casa di Amanda; insieme nella camera di Amanda e soli poichè Meredith era nella propria stanza e Rudi, come si è visto, si era trattenuto al bagno. E' quindi probabile che 
It is hard not to hear, in this phantasmagoric reconstruction of an orgiastic murder, the voice of a relatively small-town court, giving in to prejudices and suspicions excited by an attractive woman who showed noticeably little respect for local mores. Perhaps an American-style bifurcated trial might have made this sort of overheated decision making harder by excluding character evidence-though of course, an American criminal verdict would have been rendered by a jury whose prejudices could never have been examined on appeal. In any case, there is a lesson in the trial court's judgment: the continental approach depends on the professionalism of judicial officers, and where that professionalism falls short, dangers loom.

Still, the story does not end there. As Mirabella observes, the Italian system, unlike the American, does permit the close examination of judgments on appeal. The trial court's judgment was overturned on appeal in 2012, and after being reinstated, overturned again. ${ }^{237}$ The continental appellate process is designed to correct lapses in professionalism, and in this case it worked.

One more failing of the Italian system deserves mention. It is a failing that grows in a paradoxical way out of the Italian style of mercy. One of the deepest sources of frustration in the Knox case has to do with one strange fact: there was a witness who was present at the murder, but who never testified directly to what took place. That witness is of course Rudi Guede. Why do we not have the eyewitness testimony of Rudi Guede ${ }^{238}$

The answer has to do with the merciful options offered by Italian criminal procedure as reformed in 1988, and it is an answer that shows how far Italian justice is from the supposed continental commitment to getting the whole truth through inquisitorial methods. Guede requested, and was

Rudi, uscendo dal bagno, si sia lasciato trascinare da una situazione avvertita come carica di sollecitazioni sessuali e, cedendo alla propria concupiscenza, abbia cercato di soddisfare le proprie pulsioni portandosi nella stanza di Meredith che era sola nella propria camera con la porta quantomeno socchiusa .... [P]are l'ipotesi più probabile, che Rudi decise da solo di entrare nella stanza di Meredith, la reazione ed il rifiuto della ragazza dovettero essere sentiti da Amanda e Raffaele (la stanza di Amanda si trovava vicinissima a quella di Meredith) i quali, anzi, ne dovettero essere disturbati ed intervennero, per quanto la successione degli eventi ed il loro epilogo evidenziano, spalleggiando Rudi che avevano fatto entrare in casa e diventarono anche loro, insieme a Rudi, gli aggressori di Meredith, i suoi uccisori. Perché, poi, due giovani, fortemente interessati l'uno all'altra, con curiosità intellettuali e culturali, alla vigilia della laurea lui e piena di interessi lei, si determinarono a partecipare a tale azione finalizzata a forzare la volontà di Meredith con la quale avevano, specie Amanda, rapporti di frequentazione e cordialità, fino a cagionarne la morte, rientra nell'esercizio continuo della possibilità di scelta e questa Corte non può che registrare la scelta di male estremo che fu operata. Si può ipotizzare che tale scelta di male iniziò con il consumo di sostanze stupefacenti che si era verificato anche quella sera, come dichiarato da Amanda.").

237. Mirabella, supra note 33, at 253-54.

238. Guede did take the stand, and the 2014 court worked hard and impressively to extract useable information from his testimony. Nevertheless, it had to struggle with hints and scraps of information rather than the frank confession that would have eliminated all doubt in the case. 
granted, the rito abbreviato, the "abbreviated ritual," carrying with it a lightened sentence that was created in the 1988 reform. Now, Italy is not the only country to offer defendants such an option. Other systems offer lightened sentences to defendants who forego full-scale trial as well. But when other systems do so, they ordinarily extract a bargain from the defendant: they grant the lightened sentence in return for full cooperation. They offer mercy - but only to defendants who give a confession and testimony against co-offenders. To borrow a phrase from John Langbein, the procedures in other systems are designed to induce the defendant to serve as a "testimonial resource.,"239

Not so in Italy. The rito abbreviato, created in 1988, is offered as a matter of right, and there is no requirement that defendants confess and cooperate. $^{240}$ Guede has never confessed and does not cooperate; his statements to the police include an improbable account of the events intended to deny his own responsibility. He retains his constitutional right against self-incrimination and can never be compelled to testify differently. Guede was given the option of a lightened sentence, but the Italian system is so comparatively unfocused on getting the whole truth that it missed its chance to use sentencing leverage in order to get the facts. Rudi Guede, the recipient of Italian mercy, never became a testimonial resource, and that is the single most important reason why we will never know the whole truth of what happened on the night of Meredith Kercher's murder.

239. John H. Langbein, The Historical Origins of the Privilege Against Self-Incrimination at Common Law, 92 MICH. L. REV. 1047, 1053 (1994).

240. See Grande, supra note 213 , at 254 (noting that the giudizio abbreviato, the "abbreviated trial," is available to all defendants and only requires surrendering the right to a full trial). 


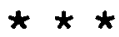

